Vučković Dejan

Rudarsko-geološki fakultet

Branislav Sretković

Centar za Nedestruktivna Testiranja i Geofiziku

d.o.o. Beograd

Dejan Miloševski

Centar za Nedestruktivna Testiranja i Geofiziku

d.o.o. Beograd

UDK 550.834:904(497.11)

Izvorni naučni članak

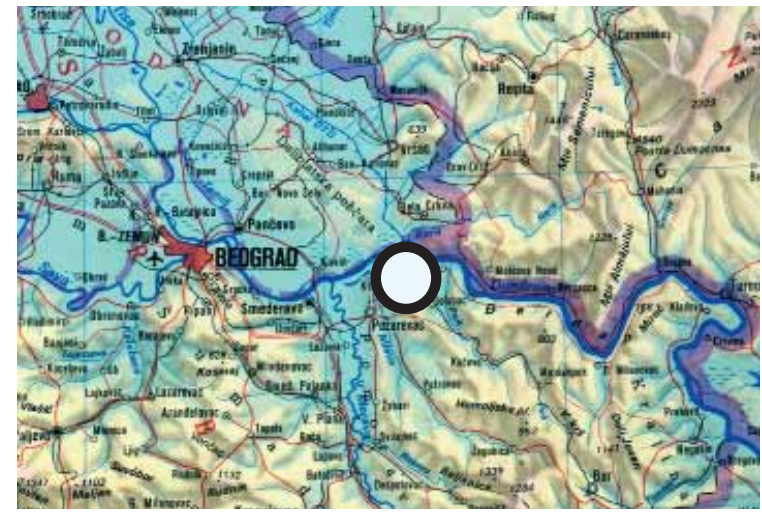

Viminacium, Stari Kostolac, Srbija

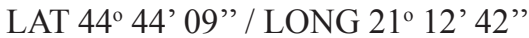

\title{
KVANTIFIKACIJA DEGRADIRAJUĆEG UTICAJA TERMOELEKTRANE DRMNO NA ARHEOLOŠKI LOKALITET VIMINACIUM
}

\begin{abstract}
APSTRAKT
U ovom radu je opisano izvođenje troaksialnog namenskog monitoringa mikrotremora i modelovanje prikupljenih podataka. Monitoring je izveden sa ciljem kvantifikacije degradacije koju termoelektrana Drmno izaziva na arheološkim ostacima lokaliteta Viminacium. Primenjen je pristup kroz analizu distribucije sadržaja spektra mikrotremora i proračun stepena degradacije u vidu zamora materijala nakon velikog broja ciklusa opterećenja, a na osnovu zamora kod čelika ČN24.
\end{abstract}

KLJUČNE REČI: SEIZMOMETRIJA, MONITORING, MIKROTREMORI, ZAMOR MATERIJALA, DEGRADACIJA

\section{UVOD}

Tokom protekle decenije, razvoj geofizike u svetu, ali i njene primene u našoj zemlji, odvijao se izuzetno velikom brzinom. Na takvu pojavu značajno je uticalo ubrzanje koji doživljava razvoj industrije personalnih računara, što otvara mogućnost razvoja sve boljih pratećih softverskih rešenja, kao i sve veće primene matematičkih numeričkih postupaka. Tako se porastom snage i mogućnosti računara, omogućava primena sve zahtevnijih matematičkih, pre svega numeričkih rešenja, a samim tim i sprovođenje izuzetno složenih i zahtevnih analiza na velikim grupama podataka. Ovo je toliko značajno za razvoj geofizike, jer omogućava izvođenje modelovanja u rezoluciji i kompleksnosti, kakva nauci, nikada ranije nije bila dostupna. Sa time u vezi je i pojava velikog broja ispitivanja, koja je danas moguće izvesti za relativno kratko vreme, dok već u protekloj deceniji, takve analize nisu bile izvodive uopšte, ili samo u ograničenoj meri. Ovaj rad opisuje izvođenje analize koja spada u grupu takvih ispitivanja.

Na lokacijama Stari Kostolac i Drmno, vršen je namenski monitoring mikrotremora, sa ciljem definisanja zona pojačanog uticaja dejstva rada termoelektrane "Kostolac B" i kvantifikovanja degradacije koju termoelektrana izaziva na arheološkim ostacima lokaliteta Viminacium. Mikrotremori predstavljaju neprekidne vibracije mikronskih amplituda (mikrovibracije) koje su stal- 
no prisutne $\mathrm{u}$ poluprostoru $\mathrm{u}$ vidu fona. $\mathrm{U}$ ovom radu prikazani su neki aspekti analize distribucije spektralnog sadržaja mikrotremora u istražnom prostoru i primenu dobijenih podataka za kvantifikaciju stepena degradacije u vidu zamora materijala.

Analiza spektra mikrotremora primenjena je za definisanje geodinamičkih parametara i kvantifikaciju njihovog uticaja na arheološke objekte. Poznavanje spektra svake tačke i njen prostorni položaj, omogućili su formiranje odgovarajućih karata istražnog prostora i modelovanje tog uticaja.

\section{ZNAČAJ LOKALITETA VIMINACIUM}

Ostaci antičkog grada Viminaciuma, glavnog grada rimske provincije Mezije Superior (Moesia Superior), u kasnoj antici provincije Mezije Prime (Moesia Prima), nalazi se u današnjim atarima sela Stari Kostolac i Drmno. Ovaj antički grad je izuzetan po mnogim elementima:

Viminacium je bio glavni grad rimske provincije Gornje Mezije, koja je u antičko vreme zauzimala približno teritoriju današnje Srbije.
Današnji Viminacium leži u sloju oranica i predstavlja prostor koji nam dozvoljava izuzetnu slobodu primene geofizičkih istraživanja.

Treba istaći da od svih legijskih logora koji su se nalazili na teritoriji nekadašnjeg Rimskog carstva, danas se samo dva nalaze na nenaseljenim prostorima. Pored Viminaciuma to je legijski logor Karnuntum nedaleko od Beča, u Austriji. Ovaj drugi logor je istražen pre više od jednog veka što doprinosi važnosti lokaliteta Viminacium. Na taj način Viminacium ostaje jedini vojni logor koji bi uz primenu modernih metoda, osim izuzetno bogatih nalaza, mogao pružiti dragocene podatke za arheologiju.

\section{GEOGRAFSKI POLOŽAJ I GEO- MORFOLOŠKE KARAKTERISTIKE TERENA}

Istražno područje se nalazi oko 90 kilometara od Beograda u blizini ušća reke Mlave u Dunav. Područje obuhvata arheološki lokalitet Viminaciuma, čiji ostaci se nalaze u oblasti današnjih sela Stari Kostolac i Drmno. Ovaj lokalitet je na desnoj obali Mlave na 700 do 800 metara od reke (slika 1). U neposrednoj blizini ovog lo-

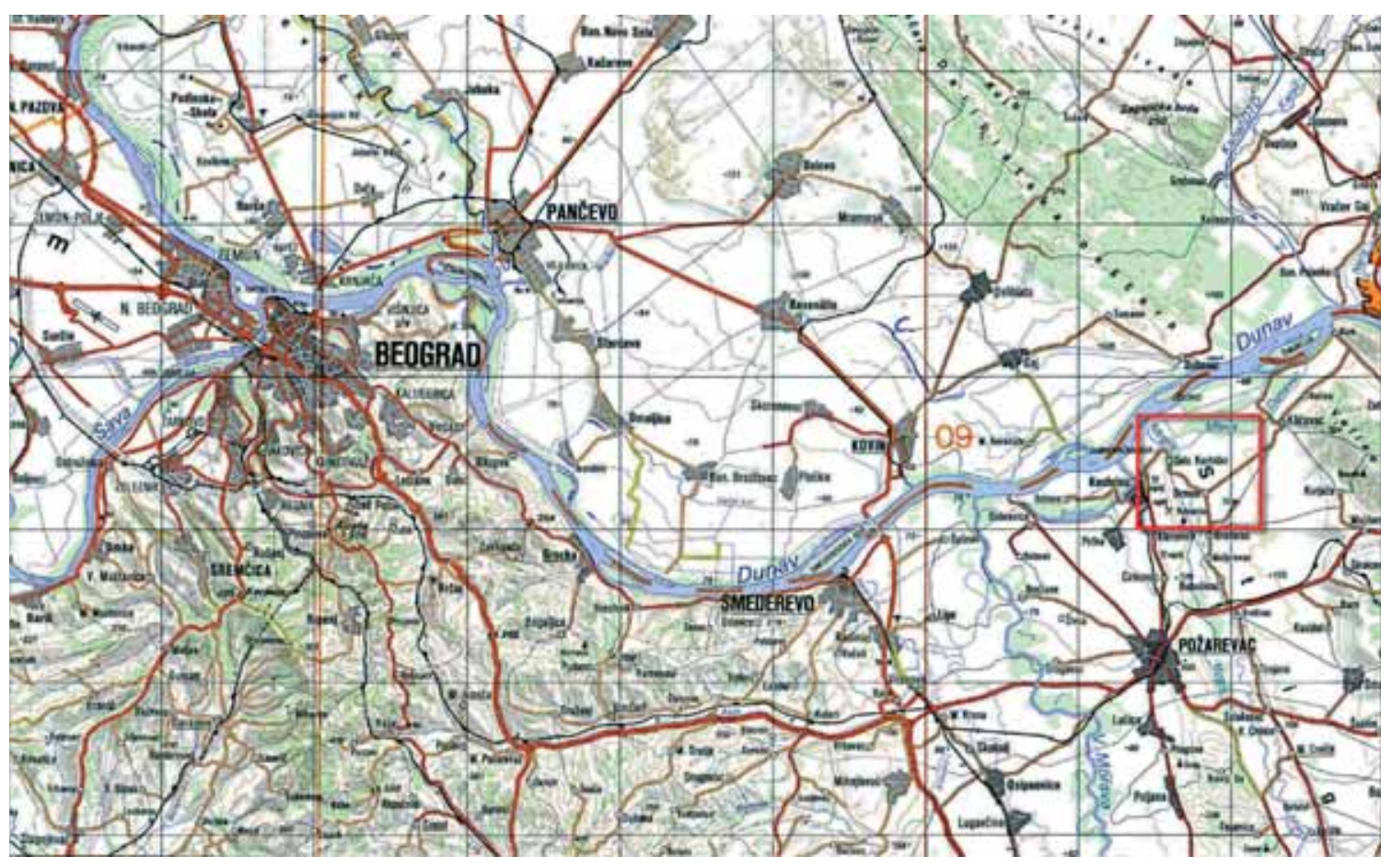

Slika 1. Geografski položaj istražnog prostora 
kaliteta prostire se površinski kop uglja - Drmno, koji snadbeva termoelektranu "Kostolac B" u neposrednoj blizini kopa.

Na priloženoj karti šira okolina istražnog prostora je uokvirena crvenom bojom. Istražno područje je povezano sa Beogradom asfaltnim putem preko Požarevca i Drmna, a dalje prema arheološkom lokalitetu vodi zemljani put.

Generalno gledano, čitav teren se može svrstati u izrazito ravničarski, sa malim uzvišenjima koja ka jugu dostižu visinu do 200 metara nadmorske visine. Reljef je oblikovan pre svega dejstvom fluvijalnog procesa. Mogu se uočiti različite facije deponovanog materijala počevši od facije starača (fosilni meandri), facija povodnja, do terasa koje su sastavljene od peskova do alverita.

Arheološki lokalitet nalazi se, nedaleko od fosilnog meandra reke Mlave na nadmorskoj visini između 80 i $90 \mathrm{mNv}$. U neposrednoj blizini istraživanog područja prostire se greben čija je nadmorska visina $174 \mathrm{mNv}$. Taj greben ustvari predstavlja deo Kostolačke grede, koja razdvaja doline Mlave i Velike Morave. Na terenu je prisutna kultivisana biljna zajednica koja se sastoji od žitarica i voćnjaka.

Današnji reljef ovog područja veoma je iz- menjen antropogenim uticajem. Vađenjem uglja na velikoj površini, u potpunosti nedostaju desetine metara tla, peska, pogrebene zemlje, gline, sve do kota od oko $25 \mathrm{mNv}$ (slika 2), odnosno oko 50 metara ispod današnje kote Dunava, severno od Viminaciuma.

\section{GEOLOŠKA GRAĐA TERENA}

Geološka građa terena preuzeta je iz tumača osnovne geološke karte (OGK), lista Bela Crkva, razmere 1:100 000 (slika 3). Na istražnom području izdvaja se nekoliko geoloških jedinica neogene i kvartarne starosti.

\section{LITOSTRATIGRAFSKE JEDINICE}

\section{Pliocen (Pl)}

Pont (P11) - u okviru donjeg pliocena izdvojena je kostolačka facija koja izgrađuje jugozapadne delove terena. Karakteriše se debelim naslagama uglja kao i prisustvom aluvijalnih sedimenata sa slatkovodnom faunom. Ovo ukazuje na visok stepen oslađivanja u obodnim delovima basena. U ovim sedimentima preovlađuje epidot i metalični minerali.

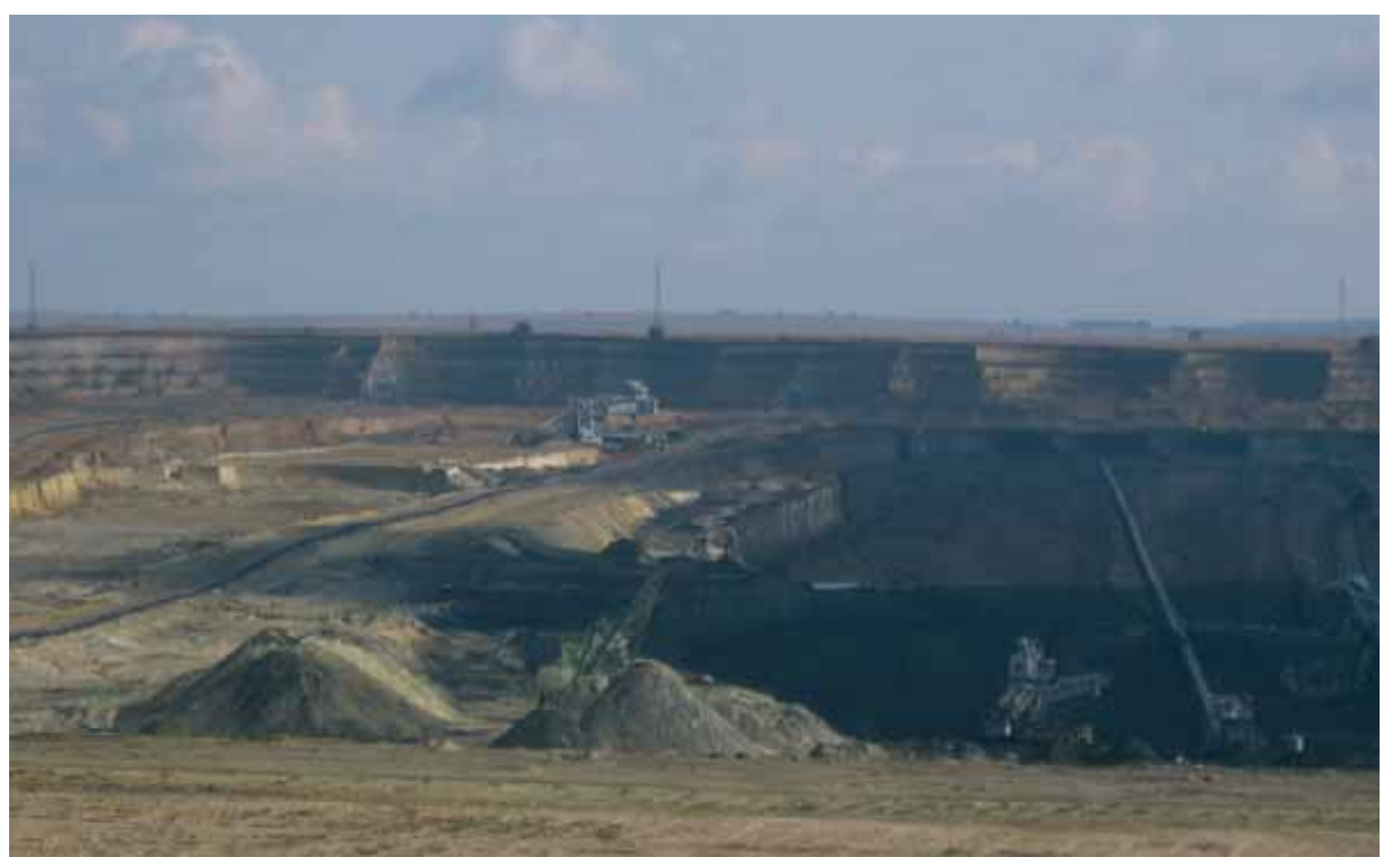

Slika 2 Izgled reljefa izmenjenog antropogenim uticajem 


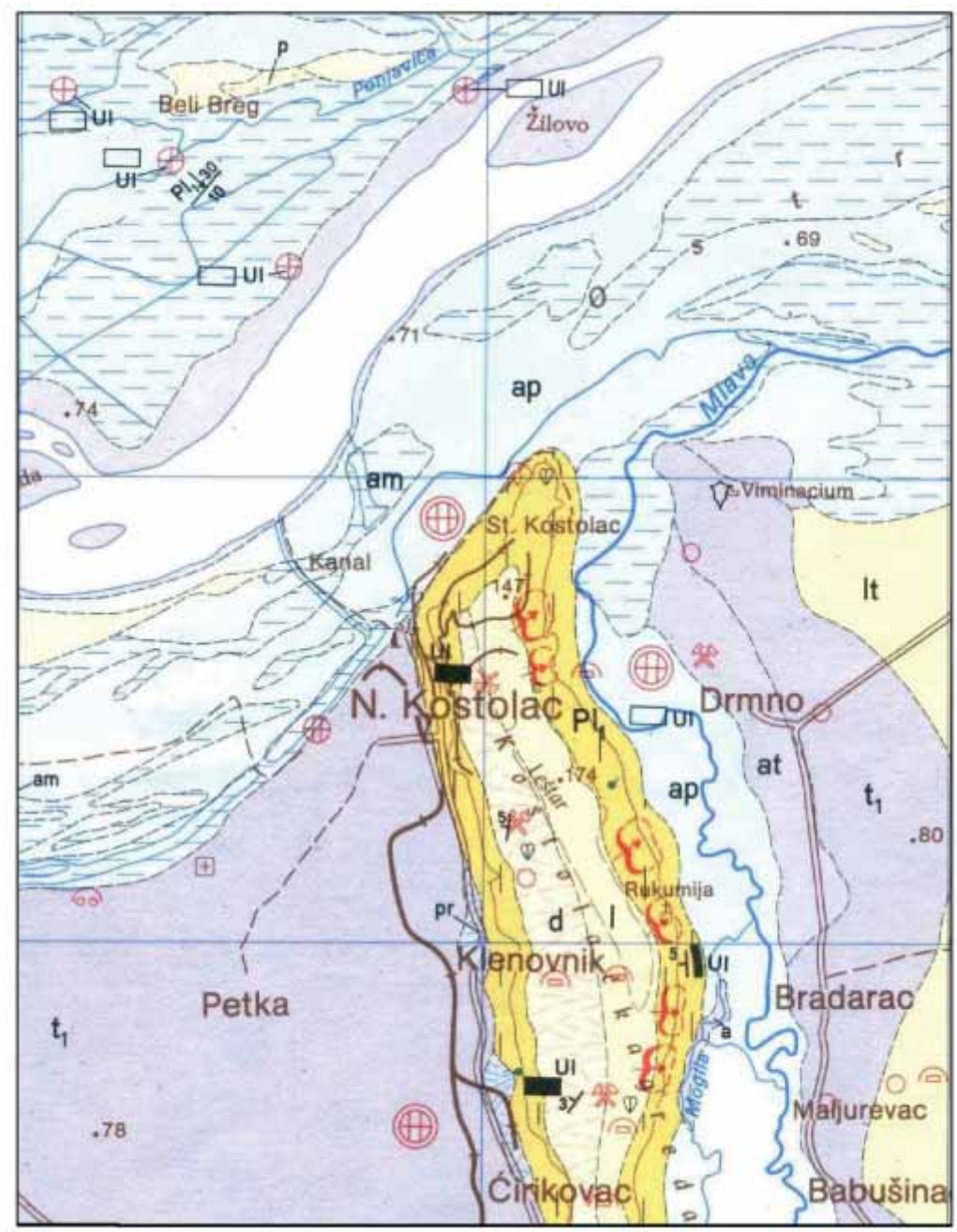

Slika 3. Geološka građa terena (OGK R=1:100.000) list Bela Crkva

Legenda standarnih oznaka

/ Normalna geološka granica utvrđena i predpostavljena

Elementi pada sloja:

s. normalani,

pojedinačna merenja

$\circ \infty$

Mikroflora, bočatna mikrofauna

$\square u$ - Izdanci uglja: UI-lignit, Um-mrki

$\infty$

Ležište peska,svrtlanj

Važnija gliništa ,važnij kamenolomi građevinskog kamena

Duboke bušotine: preko 50 komada, 20-50 komada

* J Jamski rad: aktivan, napušten

由 Klizišta

izvor
Legenda litostratigrafskih o znaka

Aluvijum; facija korita:

sljunkovi i peskovi

Aluvijum; facija povodnja: peskovi alevriti

Aluvijum; facija starača: gorski peskovi i alevriti

Aluvijum; terasa (3-5m): alevritim i peskovi

Deluvijum: lesoidni alevriti

Eolski peskovi morfoloski neuobličeni

Aluvijalna terasa $(7-12 \mathrm{~m})$ : šljunkovi, peskovi i alevriti

Eolski pesak

Lesna terasa (25-35m): šljunak, pesak i lesoidni alevriti

Pont: peskovite gline i ugalj; peskoviti krečnjak i karbonatni pesčari (a) 


\section{$\operatorname{KVARTAR}(\mathbf{Q})$}

Lesna terasa (1t) - ovaj jedinica se nalazi na 25 do 30 metara visine iznad okolnog terena. Karakteriše se 3 do 6 metara širokim temenom blago nagnutim niz tok reke. Zaleđe terena i njen odsek, često su maskirani procesima spiranja. U pogledu morfologije, jedinaca je izgrađena iz dva dela:

stariji deo - otkriven samo bušotinama, a predstavljen šljunkovito - peskovitim sedimentima; odlikuje se brzom promenom sastava. Najverovatnije je stvaran $\mathrm{u}$ vreme mindel - risa.

mlađi deo - izgrađen od peska, alevritskog peska i peskovito - glinovitih alevrita. Sedimenti se javljaju u vidu dva, tri nivoa lesa predvojenih humusnim zonama. Pronađena fauna ukazuje na sedimente stvarane u Risu i Virmu.

Eolski les (1) - naslage eolskog peska nalaze se na Kostolačkoj gredi. Odlikuju se žućkastom do svetlo smeđom bojom i velikim sadržajem alverolita i promenljivim količinama glinovitih i peskovitih čestica. Postoje 3 do 4 lesna horizonta koja su odvojena pogrebenom zemljom. Pogrebene zemlje se od lesa razlikuju nešto glinovitijim sastavom, mikrogrudvastom građom i prisustvom humusa od koga dobijaju smeđu boju. Fosilni kompleksi pridapaju podzolu, černozemu i gajnjačama.

Aluvijalne terase (at) - prostiru se na desnim obalama Velike Morave i Mlave nizvodno od Batovca tj. Bradarca. Odlikuju se terasastim uzvišenjima visine od 7 do 12 metara i postojanjem dva dela na vertikalnom profilu:

facija korita - donji deo koji je predstavljen srednjozrnim i krupnozrnim šljunkom i peskom deblljine 4 do 8 metara, ređe se sreću i peskoviti alevriti.

facija povodnja - gornji deo izgrađen od alevritskog peska i peska. U donjem delu ove facije konstatovana je kopneno - barska fauna.

Deluvijalni zastori (d) - nalaze se na zapadnim padinama Kostolačke grede i Klenovnika koji su izgrađeni od neogenih i starijih kvartarnih naslaga. U struktunom pogledu preovlađuju alevriti i pesak lesoidnog porekla. Sadrže dosta šljunka, koji se javljaju u vidu pojedinačnih zrna. Uz zonu spiranja sedimenti su krupnijeg zrna i javljaju se u obliku sočiva, dok su u perifernim delovima akumulacione zone dosta sitniji i bez šljunka.

\section{Aluvijum (AL)}

facija starača, peska, alevrita i treset (am) nastala je u napuštenim koritima Velike Morave, Dunava i Mlave. U odnosu na ostale aluvijalne sedimente nalazi se u obliku sočiva u faciji korita i na površini akumulativne ravni. Predstavljena je glinovitim alevritima, alevritskim peskom, alevritskim glinama i tresetom. Debljina ovih sedimenata iznosi od 3 do 4 metra.

facija povodnja, peska i alevrita (ap) - ove naslage najčešće pokrivaju celu aluvijalnu ravan. Karakterišu se sedimentima finijeg zrna, sitno sočivastim laminacijama, horizontalnom slojevitošću, prisustvom barsko - kopnene faune i niskim sadržajem kalcijum karbonata (CaCO3). Izgrađena je od alevritiskog peska i peskovitih alevrita sa sočivima sitnog šljunka. Debljina alevrita iznosi od 2 do 5 metara.

\section{TEKTONSKI SKLOP}

U široj okolini istražnog prostora mogu se uočiti tri krupna strukturna kompleksa: prebasenski (A), basenski tj. banatsko - moravski (B) i postbasenski tj. dunavski (C) (slika 4). Lokalitet Viminacium nalazi se u okviru basenskog (banatsko - moravskog) kompleksa. Ovaj kompleks se odlikuje strukturnim nizovima tj većim brojem horstova i rovova. Granice između strukturnih nizova predstavljaju strme površine.

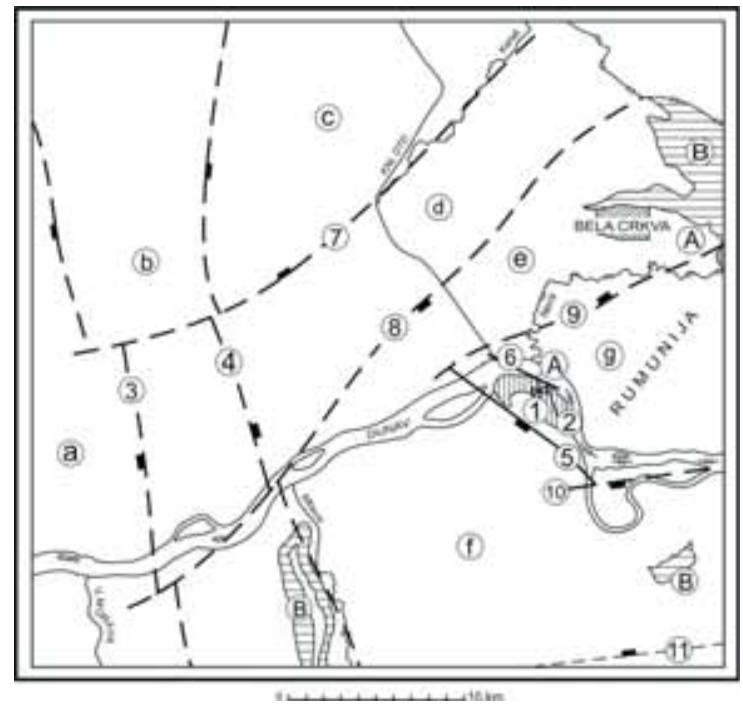

Slika 4. Karta tektonskog sklopa lista OGK Bela Crkva 
Ovi nizovi su orijentisani u dva osnovna pravca: uporedničkom na kome se nalazi Kovinski rov (a) i horst Petke (b) i podnevačkom u okviru koga su izvojeni rovovi Zagajice (d), Bele Crkve (e) i Mailovca (f). Ispitivani teren obuhvata rov Mailovca koji predstavlja depresiju meridijanskog pravca nastalu spuštanjem između horstova Orijaka i Ranovca (na listu Požarevac). Srednji delovi su od panonskih naslaga dok se na krajnje severnom delu nalaze skoro horizontalne pontijske tvorevine. Odlikuje se asimetričnošću i zone najvećih dubina nalaze se uz strukturni prag.

\section{Mineralne SIROVine}

Sem gasnih ležišta, koja se nalaze na kontaktu kristalastih škriljaca i mlađih sedimenata, sve ostale korisne mineralne sirovine genetski su vezane za neogene i kvartarne naslage. Ležišta uglja konstatovana su u Kostolačkom basenu između Kličevca i Velike Morave na površini oko $130 \mathrm{~km}^{2}$. Ova ležišta su genetski vezana za faciju takozvanih pomorskih tresova.

Ugljonosni slojevi imaju ukupnu debljinu oko 40 metara, ali se debljina znatno razlikuje kod svakog sloja zavisno od stepena raslojenosti. Ugalj pripada grupi lignita i odlikuje se prostom geološkom građom i malom izmenljivošću. $\mathrm{Na}$ ovom području pored uglja su zastupljena i ležišta gline, kvarcnog peska, treseta kao i ciglarske zemlje [2].

\section{TEORIJSKE POSTAVKE SEIZMOMETRIJE (ELASTIMETRIJE)}

Pri ovom istraživanju primenjena je seizmometrijska metoda (postupak mikrotremora), pa će u ovom poglavlju biti iznete osnove teorije elastičnosti, kao i vrste i načini prostiranja seizmoakustičkih talasa u elastičnoj sredini. Takođe, će biti bliže objašnjeni mikrotremori, kao i korišćeni merni instrumenti.

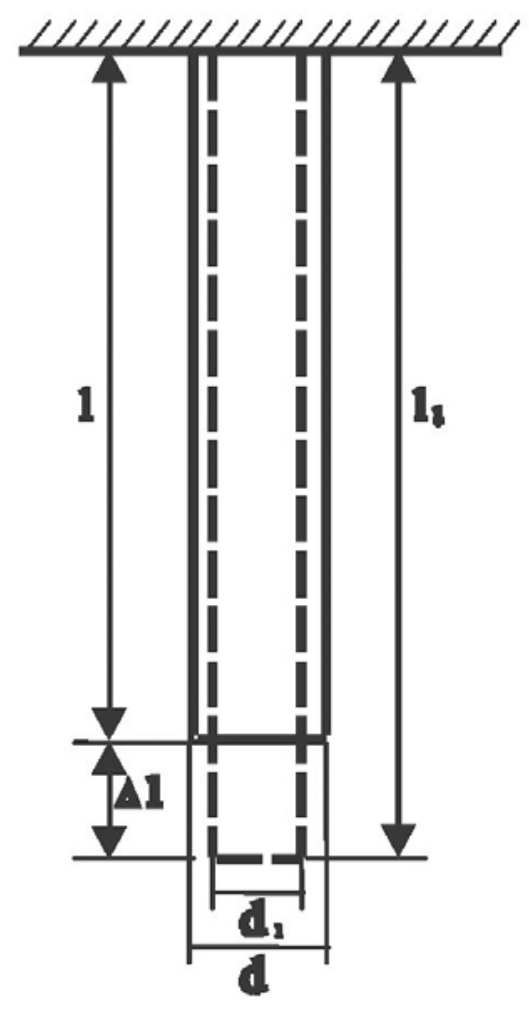

Slika 5. Istezanje šipke, Hukov zakon

\section{OSNOVI TEORIJE ELASTIČNOSTI}

Zemlja se uz izvesne aproksimacije i ograničenja može tretirati kao elastična sredina, te je za definisanje prostiranja seimoakustičkih talasa, neophodno definisati odnos između deformacija, napona i parametara elastičnosti.

Pod dejstvom sile, sredina menja svoj oblik. Telo trpi elastične deformacije ako nastale deformacije nestanu po prestanku dejstva sile. Idealno elastično telo u potpunosti dobija svoj prvobitni oblik kada prestane dejstvo sile (u prirodi ne postoje idealna elastična tela). Čvrsta tela se opiru ne samo kompresiji (sabijanju) i dilataciji (istezanju) već i svakoj promeni oblika. Fluide (gasove i tečnosti) karakteriše samo zapreminska elastičnost, odnosno oni se opiru sabijanju ili istezanju, ali ne i promeni oblika.

Da bi se definisala veza između sile (F) koja dejstvuje na čvrstu elastičnu sredinu i deformacije koja se u tim sredinama javlja, posmatra se šipka (slika 5) koja ima dužinu (l) prečnik (d) i površinu (S). Ova šipka je jednim krajem učvršćena, a na drugom kraju opterećena podužnom silom. 
Pri delovanju ove sile dolazi do istezanja ili sabijanja, te šipka postiže novu dužinu (11). Promena dužine $(\Delta \mathrm{l})$ šipke u pravcu dejstva sile je:

$$
\Delta l=l_{1}-l
$$

Što je šipka duža to će izduženje ili sabijanje biti veće. Tako se deformacija (promena dužine) može predstaviti i relacijom:

$$
\Delta l=k \cdot l
$$

Simbol k predstavlja koeficijent proporcionalnosti i zavisi od svojstva materijala od koga je šipka izgrađena. Sa druge strane, odnos sile zatezanja koja deluje na površinu i te površine, predstavlja normalni napon $(\sigma)$. Normalni napon izaziva promenu dužine i zapremine tela, a može se izraziti kao:

$$
\sigma=F / S,
$$

Normalni napon skaliran koeficientom proporcionalnosti predstavlja modul podužne elastičnosti i naziva se Jungov modul (E):

$$
\frac{\Delta l}{l}=k \Rightarrow \frac{\sigma}{k}=E \Rightarrow E=\frac{l}{\Delta l} \cdot \frac{F}{S}
$$

Jungov modul definiše elastična svojstva sredine, i što je njegova vrednost veća potreban je i veći napon da šipka promeni svoju dužinu za $\Delta$ l. Jedinica za Jungov modul je Paskal $(\mathrm{P}=\mathrm{N} /$ $\mathrm{m} 2$ ). Pored izduženja, usled delovanja normalnog napona dolazi i do promene poprečnog preseka. Osnos između relativne promene prečnika šipke i relativne promene dužine šipke naziva se Poasonov koeficijent $(v)$, koji je dat u obliku:

$$
v=\frac{\Delta d}{d} \cdot \frac{l}{\Delta l}
$$

Poasonov koeficijent je neimenovani broj, čija vrednost varira u granicama od 0,05 do 0,45 (gornja granica je 0,5). Jungov modul i Poasonov koeficijent dovoljno tačno definišu elastična svojstva homogene, izotropne i čvrste sredine. Ove karakteristike elastične sredine mogu se izraziti i preko Lameovih koeficijenata $(\lambda$ i $\mu)$. Veza iz- među Lameovih koeficijenata, Jungovog modula i Poasonovog koeficijenta data je sledećim izrazima:

$$
\lambda=\frac{v \times E}{(1+v) \times(1-2 v)}
$$

$$
\mu=\frac{E}{2(1+v)}
$$

U čvrstim stenama, pored sabijanja i istezanja, moguće su i deformacije smicanjem. Pri čistom smicanju rastojanje između paralelnih elemenata forme ostaje isto. Odstupanje od vertikalne linije je najmanje na donjoj, a najveće na gornjoj površini (slika 6).

Deformacija smicanja definiše se preko izraza datog u obliku:

$$
\frac{\overline{A A^{\prime}}}{\overline{O A}}=\frac{\overline{B B^{\prime}}}{\overline{O B}}=\frac{\overline{C C^{\prime}}}{\overline{O C}}=\operatorname{tg} \alpha=k
$$

Konstanta (k) naziva se relativno smicanje, a jednaka je tangensu ugla smicanja. Ova vrednost je konstantna za određeni materijal ako je i sila koja deluje na njega konstantna. Shodno Hukovom zakonu, kada na čvrsto telo u obliku kocke, na stranici površine $S$, deluje sila $F$ pod uglom $\varphi$, efektivni tangencijalni napon je u obliku:

$$
\tau=\frac{F}{S} \cdot \sin \varphi
$$

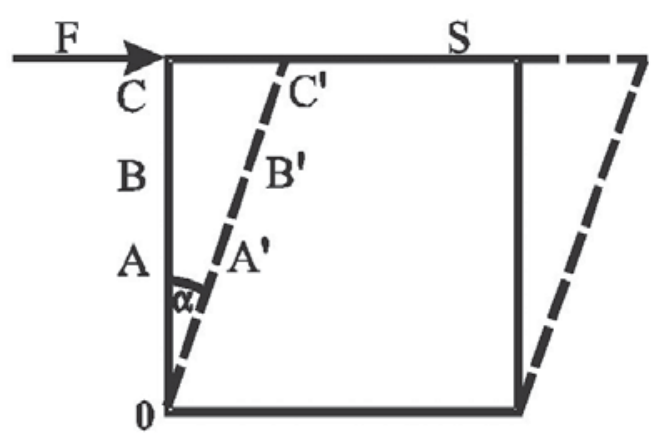

Slika 6. Prikaz idealnog smicanja 
Dejstvom tangencijalnog napona dolazi do promene oblika tela. Odnos između tangecijalnog napona i izazvane deformacije u vidu relativnog smicanja je:

$$
G=\frac{\tau}{k}
$$

Naziva se modul smicanja.

\section{VRSTE I PROSTIRANJE SEIZMOAKUSTIČKIH TALASA}

Ako se beskonačna ili polubeskonačna, čvrsta, izotropna sredina pobudi dejstvom sile, dolazi do njenog naprezanja, tj. do oscilovanja materijalnih čestica i širenja deformacija u svim pravcima. Ukoliko se takav poluprostor aproksimuje elastičnom sredinom, zakonitosti prostiranja seizmoakustičkih talasa kroz poluprostor definiše teorija elastičnosti. Materijalne čestice u unutrašnjosti, pri deformacijama izvode harmonično kretanje. Prenošenje oscilacija, s jedne do n-te čestice naziva se kretanjem talasa. Homogeno izotropno elastično telo, u svojoj unutrašnjosti, prenosi dve vrste seimoakustičkih talasa različitih brzina prostiranja. Svojstva tih talasa zavise, s jedne strane, od prirode pobude, a sa druge strane od elastičnih svojstava sredine kroz koju se talasi prostiru.

Ako je izvor pobude tačkastog oblika, površina koja povezuje tačke sa istom fazom $i$ intenzitetom napona, imaće sferni oblik i naziva se sferni talasni front. Radijus sfere se tokom vremena povećava, a koeficijent proporcionalnosti je brzina prostiranja talasa. Na većim udaljenostima talasni front se može smatrati ravanskim talasom. Geometrijsko mesto tačaka do kojih talas dopire u određenom momentu naziva se izohrona. Linije koje prolaze kroz tačku pobude, a normalne su na talasni front nazivaju se seimoakustičkim zracima.

Seizmoakustički talas na putu kroz elastičnu stensku masu, postepeno gubi energiju i slabi (izaziva sve manja naprezanja u steni), sve dok se na određenom rastojanju od mesta izvora potpuno ne priguši. Seizmoakustički talasi se prostiru od izvora u obliku koncentričnih sfera, sve do površine zemlje. Kada ovi talasi dospeju do površine, nailazeći na akustički znatno ređu sredinu (vaz- duh), izazivaju pomeranje površine tla. Takvo kretanje površine tla naziva se površinskim talasima. Postoji nekoliko tipova ovih talasa, od kojih su najznačajniji Rejlijevi i Loveovi talasi.

Kod Rejlijevih talasa, čestice se kreću eliptično i unazad u gornjem delu orbite. Loveovi talasi, ispoljavaju se u ravni površine terena, a čestice se harmonično kreću upravno na pravac prostiranja talasa.

\section{MIKROTREMORI (MIKROVIBRACIJE)}

Svojstvo seizmoakustičkih talasa da se kroz fizičke sredine različitih elastičnih karakteristika prostiru različitim brzinama, praktično je iskorišćeno za posredno ili neposredno rešavanje različitih geofizičkih zadataka u domenu arheologije, ekologije, građevine, hidrogeologije, rudarstva itd. Geofizička metoda koja svoje postupke zasniva na efektima prostiranja seizmoakustičkih talasa kroz poluprostor i vezana je za deformacije koje se javljaju u sredinama sa različitim fizičkim svojstvima, naziva se seizmometrija odnosno elastimetrija.

Istraživanja mikrotremora počela su sa razvojem seizmografa krajem prošlog veka, a odnosila su se na proučavanje njihove fizičke povezanosti sa zemljotresima. Kasnije su proširena i na vibracije tla $\mathrm{i}$ fundamenata izazvane radom mašina. Interes za njihovo proučavanje rastao je sa razvojem seizmometrije.

Mikrovibracije su dugotrajne (neprekidne) vibracije poluprostora malih amplituda - od nekoliko milimikrona do nekoliko mikrona u širokom dijapazonu perioda - od nekoliko stotih delova sekunde do nekoliko sekundi. Njihove predominantne periode predstavljaju važnu karakterisiku, jer odražavaju periode sopstvene oscilacije tla. Istraživanja varijacije mikrotremora u vremenu tj. u toku dana i noći, pokazala su da su promene predominantnih perioda mnogo manje od promene amplitude. To pokazuje da predominantne periode mikrovibracija predstavljaju sopstvenu karakteristiku lokacije.

Permanentno oscilovanje Zemljine kore delom predstavlja posledicu Zemljinih endogenih sila (termo-nuklearnih, gravitacionih, inercionih, rotacionih i dr.) i egzogenih sila (privlačna sila Sunca i Meseca, promene Sunčeve aktivnosti i 
dr.). Ovakva oscilovanja imaju vrlo velike periode $u$ intervalu od reda dana do reda godine i nisu predmet ovog razmatranja.

Mikrotremore izazivaju brojni izvori koji se javljaju proizvoljno i sa promenljivom gustinom u bližoj ili daljoj okolini ispitivanog mesta. Najčešći izvori su saobraćaj, rad mašina, motora i generatora, razne ljudske delatnosti, vetar, kiša, promena atmosferskog pritiska, rečni tokovi i talasi vodenih površina, plima, oseka, geotermalne i geohemijske reakcije i drugi slični izvori na površini i unutrašnjosti zemlje. Priroda i sadržaj spektra mikrotremora ispitivani su upoređivanjem sa karakteristikama površinskih talasa i geomehaničkim karakteristikama tla.

Spektri mikrotremora na istom mestu u različito vreme pokazuju značajne razlike. Na mestu opservacije njihov spektar zavisi od prirode i mehanizma pobude, od karakteristika sredine kroz koju se pobuđeni talas širi i od lokalne osobine poluprostora. Uticaj lokalnih osobina elastičnosti poluprostora veći je ukoliko su fizičko - mehaničke osobine poluprostora više izdiferencirane. Tada se na granicama slojeva odvija intenzivnija refleksija i interferencija talasa što značajno povećava stacionarnost i spektralnu stabilnost mikrovibracija.

Sa druge strane, što su izvori pobude udaljeniji, generisani talasi prodiru kroz dublje slojeve i bivaju u većoj meri amplitudno i frekventno modifikovani, zbog čega u sastavu mikrotremora opada uticaj kakakteristika pobude. Ovo ukazuje da se pažljivom kontrolom ambjentalnih uslova mikrovibracija može bitno uticati da oni odraze lokalne karakteristike sredine.

Pri sprovedenom istraživanju korišćena je savremena digitalna opremom. Terensko osmatranje spektralnog sadržaja mikrovibracija obavljena je upotrebom troaksijalniog elektrodinamičkog senzora (Geospace LP) i akvizicijonim sistemom TM-3C400. TM-3C400 je digitalni 24bit-ni uređaj sa integrisanim GPS prijemnikom i autonomnim napajanjem. Podaci prikupljeni ovom prilikom su simultano smeštani na memoriju računara. Dužina uzorkovanja na pojedinačnoj tački iznosila je 60 sekundi, sa periodom semplovanja od 2,5 ms. Zapis na svakoj tački sadrži po 24000 podatka u tri ose. Orijentacija senzora bila je takva da je $\mathrm{X}$ osa uvek bila usmerena u pravcu severa, $\mathrm{Y}$ osa u pravcu istoka, a $\mathrm{Z}$ osa je vertikalna.

\section{UTICAJ MIKROVIBRACIJA NA OBJEKTE}

Kada seizmoakustički talas dospe do neke tačke u poluprostoru, čestice pod njegovim uticajem bivaju »izbačene« iz svog ravnotežnog položaja. Pobuđene čestice osciluju oko svog ravnotežnog položaja dok se oscilacije ne priguše. Takvo oscilovanje čestica manifestuje se kao potres. Jedan takav permanentni uticaj nastaje zbog efekta rada velikih mašina i postrojenja, i može da izazove oštećenja objekata, naročito onih koji su već oštećeni. Zbog toga su antički objekti pod uticajem mašina koje izazivaju vibracije, daleko teži za održavanje od savremenih objekata.

Intezitet veštački prouzrokovanih vibracija (mašine, postrojenja, itd...), kvantifikuje se određivanjem dva osnovna parametra To su: brzina oscilovanja čestica tla (V) i amplituda oscilacija tla (x). Pored ovoga, često se koristi parametar ubrzanje tla (a), koji se izvodi kao diferencijal brzine po vremenu. Na osnovu ovih parametara i podataka o elastomehaničnim osobinama materijala, mogu se odrediti inteziteti sile koja ih je izazvala. Postoji više pristupa definisanju stepena ugroženosti od prisustva vibracija, koji će u daljem radu biti detaljnije izloženi. Ovi izrazi su po pravilu empirijski, i uglavnom su definisani za prigušene vibracije izazvane eksplozijom, mada ima i onih definisanih za permanentno dejstvo vibrirajućih mašina. Za potrebe ovog rada analizirano je više dostupnih izraza i tabela, kao i literatura koja obrađuje ovu oblast.

\section{FormulaCIJA VIBRACIJA}

Dinamički parametri vibracije mogu se prikazati kao

$$
\begin{aligned}
& x=A \sin (\omega t) \\
& V=A \omega \cos (\omega t)=2 \pi A \\
& a=A \omega^{2} \sin (\omega t)=4 \pi^{2} f^{2} x
\end{aligned}
$$

gde su: V - brzina oscilovanja pobuđene sredine, $\mathrm{m} / \mathrm{s}$ 


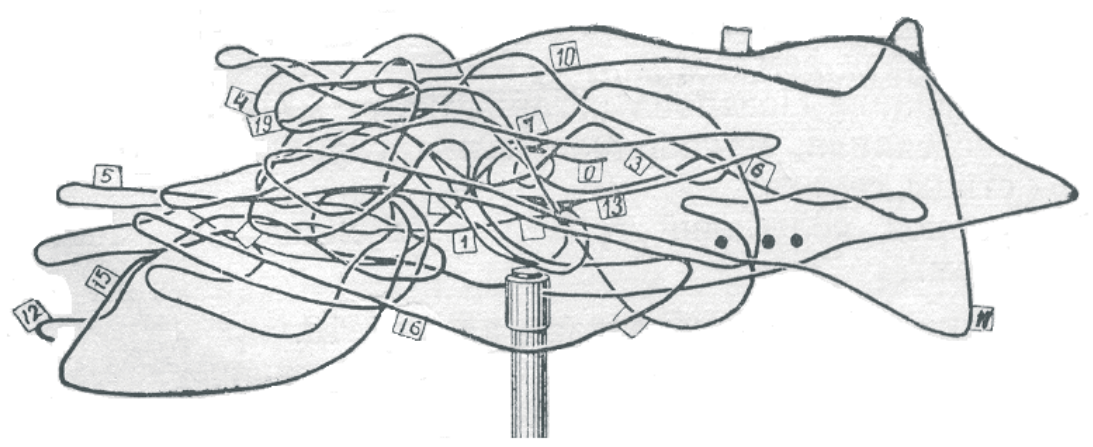

Slika 7 Putanja oscilovanja čestica poluprostora

dine, $m$

A - amplituda oscilovanja pobuđene sre-

f - frekvencija oscilovanja pobuđene sredine; $1 / \mathrm{s}$

a - ubrzanje pobuđene sredine, $\mathrm{m} / \mathrm{s} 2$

$\mathrm{x}$ - pomeranje od ravnotežnog stanja, $\mathrm{m}$

$\mathrm{t}-$ vreme (s)

$\omega-2 \pi f$.

Registrovanje potresa poluprostora: Pri pobuđivanju tla seizmoakustički talasi u tački osmatranja pristižu gotovo istovremeno, pri čemu izazivaju kretanje čestica poluprostora u različitim pravcima. Čestice pri tome osciluju u prostoru i vremenu po vrlo složenoj putanji (slika 7). Da bi u nekom trenutku bilo moguće definisati intezitet potresa kao i pravac delovanja rezultantne sile, potrebno je potrese registrovati u tri pravca (slika 8).

Registrovanje se vrši preko:
- Horizontalne komponente, normalne na pravac prostiranja talasa - poprečna - transverzalna komponenta $(\mathrm{Vt})$

- Horizontalne komponente, oscilovanje u pravcu prostiranja talasa - uzdužna - longitudinalna komponenta (Vl)

- Vertikalne komponente (Vv)

Kao parametar za ocenu seizmičkog dejstva mašina i postrojenja najčešće se uzima brzina oscilovanja pobuđenog poluprostora. Smatra se da da brzina najbolje opisuje rizik od vibracija i štete koje mogu izazvati. Zbog toga su i odgovarajući standardi za zaštitu od potresa bazirani na njoj.

Ako se pri ispitivanjima na terenu registovanje brzina vrši senzorima sa tri komponente, sa dobijenog dijagrama (velosigrama) može se odrediti rezultirajuća maksimalana brzina oscilovanja sredine po formuli:

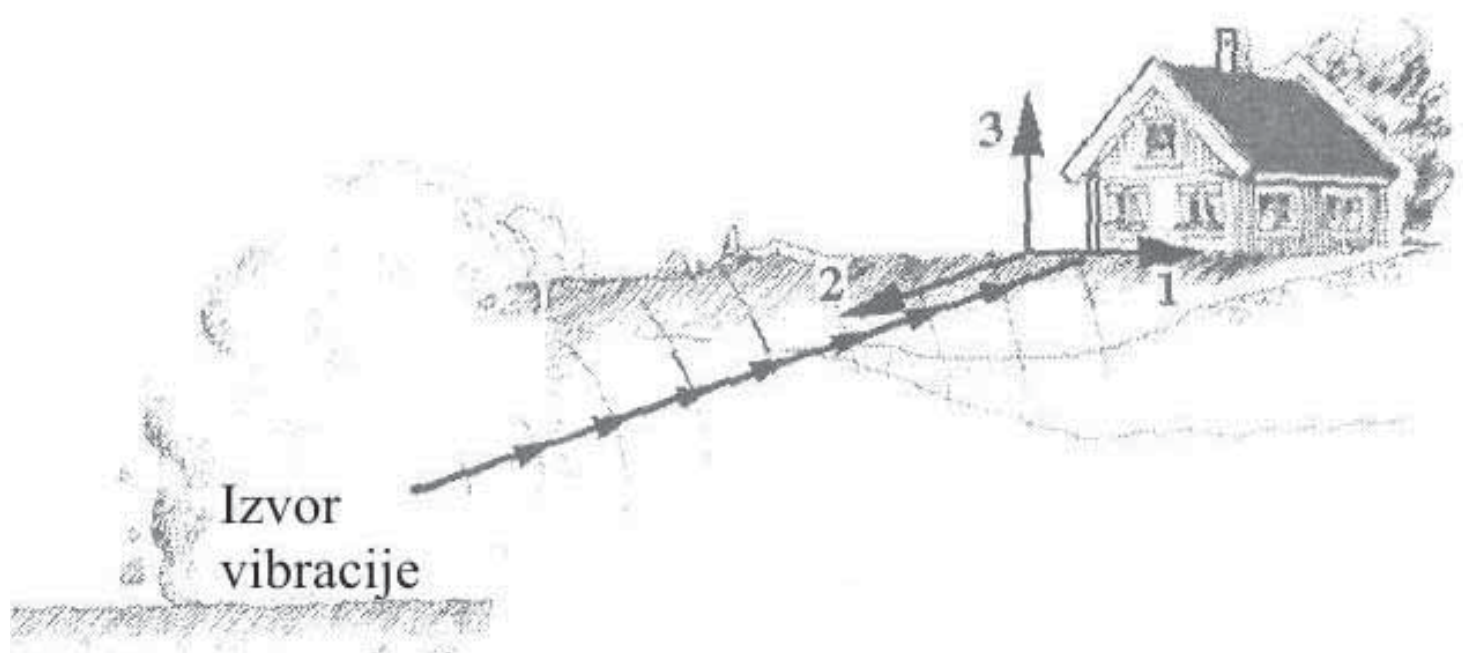

Slika 8. Položaj komponenti pri osmatranju potresa u odnosu na mesto izvora vibracija, 1 - poprečna, 2 - uzdužna, 3 - vertikalna komponenta 


$$
V_{\max }=\sqrt{V_{t}^{2}+V_{v}^{2}+V_{l}^{2}}(\mathrm{~m} / \mathrm{s})
$$

Tako je moguće izračunati maksimalnu brzinu oscilovanja (Vmax) i efektivnu (stvarnu) maksimalnu brzinu oscilovanja (Vst) pobuđene sredine. Maksimalna brzina se određuje tako što se sa dijagrama očita maksimalna amplituda (posebno za svaku komponentu), a zatim se sračuna rezultujuća maksimalna brzina oscilovanja po formuli (12). Stvarna maksimalna brzina oscilovanja se dobija tako što se sa dijagrama očitaju amplitude $\mathrm{u}$ istom vremenskom trenutku za sve tri komponente, a zatim se rezultujuća stvarna brzina računa, takođe, po formuli (12).

\section{Procena Štete od VIBRACIJA I POTResa}

Radi lakše identifikacije stanja objekata koji se nalaze u neposrednoj blizini izvora stalnih vibracija daje se njihova kategorizacija prema otpornosti na potrese i oscilacije. Svi objekti su svrstani u tri osnovne kategorije, a odnose se na objekte koji nisu građeni po propisima.

Tip A - zgrade koje su građene od neobrađenog kamena, seoske zgrade od nepečene cigle, zgrade sa zidovima oblepljenim blatom, najmanje su otporne na potrese i vibracije

Tip B - zgrade od pečene cigle, zgrade građene od blokova i montažne zgrade, zgrade od prirodnog tesanog kamena, kao i zgrade sa delimično drvenom konstrukcijom.

Tip C - zgrade građene sa armirano - betonskom konstukcijom i dobro građene drvene kuće. Ovaj tip građevina je i najotporniji na potrese i vibracije.

Objekti koji su u slučaju Viminaciuma izloženi uticaju mikrovibracija prema gore navedenim kategorijama pripadaju tipu A, s tim što se mora uzeti u obzir i njihova starost. Ovi arheološki objekti su građeni pre oko dve hiljade godina, a građeni su od opeke, kamena i tadašnjeg maltera, što ih čini još osetljivijim na potrese. Da bi se lakše utvrdilo stanje objekta, bilo da je ranije bio oštećen, ili da je neoštećen, neophodna je klasifikacija oštećenja koja je već poznata i koja se koristi u seizmologiji (tabela 1).

Na osnovu ove tabele oštećenja objekata su svrstana u pet stepeni:

I stepen oštećenja - laka oštećenja. Sitne pukotine u malteru. Osipanje kreča sa tavanica, opadanje sitnih delova maltera.

II stepen oštećenja - umerena oštećenja. Opadanje manjih parčadi maltera sa plafona i zidova, male pukotine u zidovima, padanje crepova sa krova, padanje delova dimnjaka sa krova.

III stepen oštećenja - teža oštećenja. Duboke pukotine u zidovima, raslojavanje i opadanje plafona, padanje dimnjaka sa krova.

IV stepen oštećenja - razaranje. Otvorene pukotine u zidovima, rušenje delova građevine, kidanje veza između pojedinih delova zgrada, rušenje unutrašnjih zidova zgrada.

V stepen oštećenja - totalno oštećenje. Potpuno razdvajanje konstrukcije i rušenje zgrade.

Ovde je napravljena paralela između stepena oštećenja i MCS skale:
I stepen oštećenja
VI stepen MCS skale
II stepen oštećenja VII stepen MCS skale
III stepen oštećenja
IV stepen oštećenja
V stepen oštećenja VIII stepen MCS skale IX stepen MCS skale XI stepen MCS skale.

Kriterijumi za ocenu potresa: U raznim zemljama kao ulazna veličina za ocenu inteziteta potresa i procenu delovanja istih na građevinske objekte koriste se razni napred navedeni parametri. Granične vrednosti brzine oscilovanja koje objekti bez posledica podnose, varira od skale do skale. Te vrednosti zavise od terena na kojima su objekti izgrađeni, od materijala od kog su pravljeni, statičko-dinamičkih konstruktivnih svojstava, kao i od postojećeg stanja objekata (stari, novogradnja, oronuli objekti i dr.). Iz tih razloga svaka zemlja propisuje svoje kriterijume za ocenu potresa.

U našoj zemlji nisu još doneti odgovarajući propisi i zato će u daljem radu biti prikazano više skala iz različitih zemalja. Neke od tih skala se koristi i za određivanje kriterijuma kod nas.

Kriterijum u Australiji: koriste se norme DIN 4150, ali se iz propisa ne vidi koja komponenta (najvetovatnije Vst) se usvaja za graničnu veličinu (tabela 2). Radovi se prekidaju kada brzina oscilacija iznoci $5 \times 10-2 \mathrm{~m} / \mathrm{s}$.

Kriterijum u Engleskoj: za granične nivoe se usvaja maksimalna vrednost za radijalne komponente oscilacija (tabela 3 ).

Kriterijum IFZ Akademije nauka Rusije: dozvoljeni intezitet potresa za objekte vezan je za 


\begin{tabular}{|c|c|c|}
\hline Stepen & Opis efekta zemljotresa & $\begin{array}{l}\text { Maksimalno } \\
\text { ubrzanje }\left(\mathrm{m} / \mathrm{s}^{2}\right)\end{array}$ \\
\hline I & Registruju ga samo seizmografi & $<0,0025$ \\
\hline II & Reaguju samo vrlo osetljive osobe u mirovanju & $0,0025-0,005$ \\
\hline III & Oseti ga više ljudi u unutrašnjosti zgrada & $0,005-0,01$ \\
\hline IV & $\begin{array}{l}\text { U kućama ga oseti veći deo stanovnika, a na otvorenom samo } \\
\text { pojedinci. Posuđe i prozori zveckaju. Pojedinci se bude iz sna }\end{array}$ & $0,01-0,025$ \\
\hline V & $\begin{array}{l}\text { Osete ga mnogi i na otvorenom prostoru. Predmeti koji slobodno } \\
\text { vise - zanjišu se. Kod pojedinaca izaziva manju paniku }\end{array}$ & $0,025-0,05$ \\
\hline VI & $\begin{array}{l}\text { Osete ga sve osobe i beže iz kuća. Slike padaju sa zidova. Na } \\
\text { slabijim zgradama nastaju manja oštećenja. }\end{array}$ & $0,05-0,1$ \\
\hline VII & $\begin{array}{l}\text { Nastaju rušenja i razaranja uz znatne štete na nameštaju u stanovima. } \\
\text { Oštećenja se javljaju i na kvalitetnijim kućama. Ruše se dimnjaci na } \\
\text { kućama, padaju crepovi. }\end{array}$ & $0,1-0,25$ \\
\hline VIII & $\begin{array}{l}\text { Javlja se oštećenje na oko } 25 \% \text { kuća, neke slabije se ruše. U } \\
\text { vlažnom tlu i padinama javlljaju se manje pukotine }\end{array}$ & $0,25-0,5$ \\
\hline IX & $\begin{array}{l}\text { Oko } 50 \% \text { zidanih kuća znatno je oštećeno, mnoge se ruše, a većina } \\
\text { je neupotrebljiva za dalje stanovanje. }\end{array}$ & $0,5-1$ \\
\hline $\mathrm{X}$ & $\begin{array}{l}\text { Teška oštećenja nastaju na oko } 75 \% \text { zgrada, a većina njih se ruši. U } \\
\text { tlu nastaju pukotine široke do nekoliko cm. Sa padina se odranjaju } \\
\text { stene, stvaraju se velika klizišta u tlu }\end{array}$ & $1-2,5$ \\
\hline XI & $\begin{array}{l}\text { Ruše se sve zidane zgrade. U tlu nastaju široke pukotine iz kojih } \\
\text { prodire voda sa peskom i muljem. Javlja se veliko odranjavanje }\end{array}$ & $2,5-5$ \\
\hline XII & $\begin{array}{l}\text { Nijedan veštački objekat ne može opstati. Tlo i reljef menjaju izgled, } \\
\text { zatrpavaju se jezera, reke menjaju korita }\end{array}$ & $5-10$ \\
\hline
\end{tabular}

Tabela 1 MCS skala (skraćeni oblik)

brzine oscilovanja tla i stepen seizmičkog inteziteta (tabela 4).

Dozvoljene brzine oscilovanja tla $\mathrm{u}$ temeljima objekata u zavisnosti od klase objekta, date su u tabeli 5.

Dozvoljena brzina oscilovanja kod građevinskih objekata zavisi i od vrste objekta, značaja i namene. Zbog toga je izvršena i podela objekata u četiri klase:
I klasa - naročito značajni objekti, saveznog ili republičkog značaja i arhitektonski spomenici.

II klasa - industrijski objekti od izuzetne važnosti: cevovodi, fabričke hale većih dimenzija, izvozni tornjevi u rudnicima, vodovodni tornjevi i sl. Objekti čiji je vek trajanja duži od 20 do 30 godina, stambeni objekti u kojima živi veći broj stanovnika, domovi kulture, bioskopi. 


\begin{tabular}{|l|l|}
\hline Vrsta, tip objekta & $\begin{array}{l}\text { Granična vrednost } \\
\text { brzine oscilacija, m/s }\end{array}$ \\
\hline Zgrade sa osetljivim mernim instrumentima & $1,5 \times 10^{-2}$ \\
\hline Stambene zgrade & $2,5 \times 10^{-2}$ \\
\hline Poslovne zgrade & $5 \times 10^{-2}$ \\
\hline
\end{tabular}

Tabela 2 Vrednost gtanične brzine oscilovanja za odgovarajući tip objekta

\begin{tabular}{|l|l|}
\hline Frekventno područje & Granična vrednost $\left(V_{r}\right), \mathrm{m} / \mathrm{s}$ \\
\hline do $10 \mathrm{~Hz}$ & $1,25 \times 10^{-2}$ \\
\hline od 10 do $50 \mathrm{~Hz}$ & $6,4 \times 10^{-2}$ \\
\hline
\end{tabular}

Tabela 3 Granične vrednosti za nadzemne objekte i za dva odvojena frekventna područja

\begin{tabular}{|l|l|l|}
\hline $\begin{array}{l}\text { Brzina oscilovanja tla }(V), \\
\mathrm{m} / \mathrm{s}\end{array}$ & $\begin{array}{l}\text { Stepen } \\
\text { seizmičkog } \\
\text { inteziteta }(I)\end{array}$ & Opis dejstva \\
\hline do $0,2 \times 10^{-2}$ & II & $\begin{array}{l}\text { Dejstvo se registruje samo pomoću istrumenata } \\
\text { potpuna tišina }\end{array}$ \\
\hline $0,2 \times 10^{-2}-0,4 \times 10^{-2}$ & III & $\begin{array}{l}\text { Dejstvo oseća veoma mali broj ljudi,ili samo oni koji } \\
\text { ga očekuju }\end{array}$ \\
\hline $0,4 \times 10^{-2}-0,8 \times 10^{-2}$ & IV & $\begin{array}{l}\text { Dejstvo osećaju mnogi ljudi, čuje se zveket prozor- } \\
\text { skog stakla }\end{array}$ \\
\hline $0,8 \times 10^{-2}-1,5 \times 10^{-2}$ & V & $\begin{array}{l}\text { Osipanje maltera, oštećenja na zgradama u slabom } \\
\text { stanju }\end{array}$ \\
\hline $1,5 \times 10^{-2}-3 \times 10^{-2}$ & VI & $\begin{array}{l}\text { Pojava finih prslina u malteru, oštećenja na zgradama } \\
\text { koje već imaju razvijene deformacije }\end{array}$ \\
\hline $3 \times 10^{-2}-6 \times 10^{-2}$ & & \\
\hline
\end{tabular}




\begin{tabular}{|l|l|l|}
\hline $6 \times 10^{-2}-12 \times 10^{-2}$ & VII & $\begin{array}{l}\text { Oštećenja na zgradama u dobrom stanju, pukotine u } \\
\text { malteru, delovi maltera otpadaju, fine prsline u zido- } \\
\text { vima, pukotine na zidanim pećima, rušenje dimnjaka }\end{array}$ \\
\hline $12 * 10^{-2}-24 * 10^{-2}$ & VIII & $\begin{array}{l}\text { Znatne deformacije građevina, pukotine u nosećoj } \\
\text { konstrukciji i zidovima, veće pukotine u pregradnim } \\
\text { zidovima, padanje fabričh dimnjaka, plafona }\end{array}$ \\
\hline $24 \times 10^{-2}-48 \times 10^{-2}$ & IX & $\begin{array}{l}\text { Rušenje građevina, veće pukotine u zidovima, raslo- } \\
\text { javanje zidova, obrušavanje nekih delova zidova }\end{array}$ \\
\hline veće od $48 \times 10^{-2}$ & X - XII & $\begin{array}{l}\text { Veća razaranja, stropoštavanje čitavih konstrukcija, } \\
\text { itd. }\end{array}$ \\
\hline
\end{tabular}

Tabela 4 Ocena seizmičkih inteziteta IFZ Akademije nauka Rusije

\begin{tabular}{|l|c|c|c|}
\hline \multicolumn{1}{|c|}{ Karakteristike zgrada i objekata } & \multicolumn{2}{|c|}{ Dozvoljena brzina oscilovanja tla po klasi } \\
& II & III & IV \\
\cline { 2 - 4 } & & & \\
\hline $\begin{array}{l}\text { 1) Stambene zgrade i industrijski objekti sa ar- } \\
\text { mirano- betonskom ili čeličnom konstrukcijom, } \\
\text { sa lakom ispunom, računati na seizmičke utica- } \\
\text { je. Kvalitet gradnje zadovoljavajići i bez ikakvih }\end{array}$ & $5 \times 10^{-2}$ & $7 \times 10^{-2}$ & $10 \times 10^{-2}$ \\
$\begin{array}{l}\text { izmena u odnosu na projekat i proračun. Zaosta- } \\
\text { lih deformacija u konstrudciji nema. }\end{array}$ & & \\
\hline $\begin{array}{l}\text { 2) Stambeni i industrijski objekti sa armirano- } \\
\text { betonskom ili čeličnom konstrudcijom. Zaosta- } \\
\text { lih deformacija u konstrukciji nema. }\end{array}$ & $2 \times 10^{-2}$ & $5 \times 10^{-2}$ & $7 \times 10^{-2}$ \\
\hline $\begin{array}{l}\text { 3) Zgrade kod kojih su pregradni zidovi od ope- } \\
\text { ke ili kamena. Nove ili stare kamene zgrade ili } \\
\text { zidane zgrade građenje bez seizmičkih uticaja. } \\
\text { kvalitet gradnje dobar. Zaostalih deformacija u } \\
\text { konstrukciji nema. }\end{array}$ & $1,5 \times 10^{-2}$ & $3 \times 10^{-2}$ & $5 \times 10^{-2}$ \\
\hline $\begin{array}{l}\text { 4) Zgrade koje imaju znatna oštećenja na zidovi- } \\
\text { ma i pukotine u konstrukciji. Nove ili stare zgra- } \\
\text { de od kamene ili opeke, sa manjim nepovezanim } \\
\text { pukotinama u nosećim i pregradnim zidovima. }\end{array}$ & $1 \times 10^{-2}$ & $2 \times 10^{-2}$ & $3 \times 10^{-2}$ \\
\hline $\begin{array}{l}\text { 5) Stare ili nove zgrade sa pukotinama i poki- } \\
\text { danim vezama između pojedinih elemenata. Ka- } \\
\text { mene ili zgrade od opeke sa kosim pukotinama u } \\
\text { nosećim zidovim i uglovima i sl. }\end{array}$ & $0,5 \times 10^{-2}$ & $1 \times 10^{-2}$ & $2 \times 10^{-2}$ \\
\hline
\end{tabular}


6) Oštećena armirano-betonska konstrukcija, krupne pukotine u betonu. Zgrade kod kojih noseći zidovi imaju veći broj pukotina, narušene veze između spoljašnjih i unutrašnjih zidova i sl. Zgrade građene od montažnih elemenata koje nisu seizmički obezbeđene.

Tabela 5 Dozvoljene brzine oscilovanja tla u temeljima objekta

\begin{tabular}{|l|l|}
\hline Vrsta oštećenja & Brzina osciliranja $\left(V_{s}\right), \mathrm{m} / \mathrm{s}$ \\
\hline Nema oštećenja & do $1,3 \times 10^{-2}$ \\
\hline Laka oštećenja & $1,3 \times 10^{-2}-4,2 \times 10^{-2}$ \\
\hline Srednja oštećenja & $4,2 \times 10^{-2}-13,1 \times 10^{-2}$ \\
\hline Velika oštećenja & $13,1 \times 10^{-2}-26 \times 10^{-2}$ \\
\hline
\end{tabular}

Tabela 6 Odnos vrste oštećenja i granične brzine

\begin{tabular}{|l|l|}
\hline Ugroženost objekta & $\begin{array}{l}\text { Maksimalna brzina } \\
\text { ocilovanja, } \mathrm{m} / \mathrm{s}\end{array}$ \\
\hline Sigurna & manja od $8 \times 10^{-2}$ \\
\hline Nesigurna & $8 \times 10^{-2}-12 \times 10^{-2}$ \\
\hline Ugrožena & veća od $12 \times 10^{-2}$ \\
\hline
\end{tabular}

Tabela 7 Ugroženost objekta definisana preko maksimalne brzine

III klasa - industrijski objekti i administrativne zgrade relativno malih dimenzija, čija visina nije veća od tri sprata; mehaničke radionice, kompresorske stanice, stambeni objekti u kojima živi mali broj ljudi, magacini.

IV klasa - zgrade i industrijski objekti u kojima su smeštene skupocene mašina i uređaju - a njihovo oštećenje ne ugrožava život i zdravlje ljudi; skladišta, automobilske baze i sl.

Prema ovom ruskom kriterijumu objekti Viminaciuma pripadaju I klasi kao značajni arheološki lokaliteti, i dozvoljena brzina oscilovanja tla za ovakve objekte je manja od $0,3 \times 10^{-2} \mathrm{~m} / \mathrm{s}$, negde oko $0,15 \times 10^{-2} \mathrm{~m} / \mathrm{s}$.

Kriterijum u Japanu: velosigrami se uzimaju za frekvence do $2 \mathrm{~Hz}$ (koje su dominantne za zemljotrese), a odnos između vrste oštećenja i granične brzine dat je u tabeli 6 .

Iz tabele se ne vidi koje se komponente opažaju i registruju, kao i šta se podrazumeva pod srednjom brzinom oscilovanja $\left(V_{s}\right)$.

Kriterijum u Kanadi: ovde se za granični nivo usvaja maksimalna brzina oscilovanja registrovana na bilo kojoj komponenti (tabela 7).

Granični uslovi kod ovog kriterijuma odnose se na frekventno područije od 15 do $110 \mathrm{~Hz}$ i 
za novoizgrađena objekte.

Kriterijum u Poljskoj: njihov kriterijum se odnosi na osetljivost mašina i uređaja u laboratorijima, fabrikama kao i u zgradama pri određenim vibracijama. Podela mašina po klasama osetljivosti data je u tabeli 8, dok su u tabeli 9 date dozvoljene vrednosti amplitude i brzine oscilovanja.

Ovaj kriterijum je bitan jer se odnosi na potrese čiji su izvori vibracije izazvanje radom nekih mašina i postrojenja a ne potresi izazvani eksplozijom.

Kriterijum u SR Nemačkoj: obavezno se opažaju sve tri komponente oscilovanja i registrovanje se vrši na temeljima objekata, na visini terena. Za granične vrednosti usvaja se maksimalna prividna brzina oscilovanja. Ovde je frekventni opseg od 5 do $100 \mathrm{~Hz}$ (tabela 10).

Kriterijum u Sjedinjenim Američkim Državama: daje podatke o dozvoljenoj brzini oscilovanja objekata u funkciji frekvencija. Za ocenu inteziteta vibracija usvaja se rezultantna vrednost brzine oscilovanja i vrednosti su date u tabeli 11 .

Kriterijum u Francuskoj: ovde se uzima za kriterijum istinita rezultantna brzina. U tabeli 12 data je zavisnost između graničnih brzina i očekivanih oštećenja na objektima za dva frekventna područija.

Kriterijum u Švedskoj: njihov kriterijum se zasniva na maksimalnoj vrednosti vertikalne komponente oscilovanja. Iz Tabele 13 vidi se da su za objekte važni tipovi tla na kojima su građeni, kao i da postoje dva frekventna područja.

Tlo tipa 1- pesak, šljunak, laporac ispod nivoa podzemne vode. Brzina prostiranja uzdužnog elastičnog talasa $V_{l}=300-1500 \mathrm{~m} / \mathrm{s}$.

Tlo tipa 2 - morene, škriljci, mekani krečnjak. Za njih je karakteristično $V_{l}=2000-3000$ $\mathrm{m} / \mathrm{s}$.

Tlo tipa 3 - kompaktan krečnjak, gnajs, granit, dijabaz. Odlikuju se najvećim brzinama $V_{l}$ $=4500-6000 \mathrm{~m} / \mathrm{s}$.

Kriterijum po Zelleru: Zeller štetnost i

\begin{tabular}{|c|c|c|}
\hline $\begin{array}{l}\text { Klasa } \\
\text { osetljivosti }\end{array}$ & $\begin{array}{l}\text { Karakt.osetljivosti na } \\
\text { oscilacije }\end{array}$ & Naziv mašine ili uređaja \\
\hline I & Vrlo osetlljive & $\begin{array}{l}\text { Uređaji za statističko i dinamičko vaganje, ispitivanje i re- } \\
\text { gulaciju optičkih uređaja, merni mikroskop, interferometri } \\
\text { i drugi osetljivi optički uređaji, precizne mašine za obradu, } \\
\text { kontrolno-merni uređaji tačnosti od nekoliko } \mu \mathrm{m} \text {, refrakci- } \\
\text { oni uređaji na mernim aparatima, računari. }\end{array}$ \\
\hline II & Srednje osetljive & $\begin{array}{l}\text { Mašine za izradu navoja, zupčanika, ležaja, automatske } \\
\text { bušilice i freze, bavarski strojevi sa tolerancijama od neko- } \\
\text { liko } \mu \mathrm{m} \text {, precizni automati i mašine za obradu. }\end{array}$ \\
\hline III & Malo osetljive & $\begin{array}{l}\text { Obične bavarske mašine, freze, bušilice, brusilice, mašine } \\
\text { za obradu obične tačnosti, mašine za izvlačenje, tkanje, ti- } \\
\text { pografiju. }\end{array}$ \\
\hline IV & Skoro neosetljive & $\begin{array}{l}\text { Motori, blanjalice, šiveće mašine, mašine za obradu lakih } \\
\text { metala i drveta, industrijske štamparije, sekačice. }\end{array}$ \\
\hline V & $\begin{array}{l}\text { Potpuno } \\
\text { neosetljive }\end{array}$ & $\begin{array}{l}\text { Ventilatori, drobilice, mlinovi, vibracioni stolovi i sita, } \\
\text { uređaji za prosejavanje, čekići i dr. }\end{array}$ \\
\hline
\end{tabular}

Tabela 8 Podela mašina po klasama osetljivosti 


\begin{tabular}{|l|l|l|l|l|}
\hline \multirow{2}{*}{$\begin{array}{l}\text { Klasa } \\
\text { osetljivosti }\end{array}$} & $\begin{array}{l}\text { Karakteristike } \\
\text { mašina ili } \\
\text { uređaja }\end{array}$ & $\begin{array}{l}\text { Dozvoljena maks br- } \\
\text { ziva oscilovanja pod- } \\
\text { loge } \mathrm{u} \text { jednom pravcu } \\
\left(V_{p}\right), \mathrm{m} / \mathrm{s}\end{array}$ & $\begin{array}{l}\text { Dozvoljena amplituda pomeranja pri } \\
\text { frekvenciji, } \mu \mathrm{m}\end{array}$ & $\mathrm{f}=10 \mathrm{~Hz}$ \\
\hline I & Vrlo osetljivi & $0,1 \times 10^{-2}$ & 1,6 & $\mathrm{f}=50 \mathrm{~Hz}$ \\
\hline II & Srednje osetljivi & $1 \times 10^{-2}$ & 16,0 & 0,3 \\
\hline III & Malo osetljivi & $3 \times 10^{-2}$ & 50,0 & 3,0 \\
\hline IV & Skoro neosetljivi & $6 \times 10^{-2}$ & 100,0 & 10,0 \\
\hline V & Potpuno neosetljivi & $>6 \times 10^{-2}$ & 100,0 & 20,0 \\
\hline
\end{tabular}

Tabela 9 Dozvoljene vrednosti amplitude i brzine oscilovanja

\begin{tabular}{|c|c|c|c|c|c|}
\hline & \multirow{4}{*}{ Vrsta objekta } & \multicolumn{4}{|c|}{ Orjentacione vrednosti za brzine $(V), \mathrm{m} / \mathrm{s}$} \\
\hline & & \multicolumn{3}{|c|}{ Temelj } & \multirow{3}{*}{$\begin{array}{l}\text { Tavanice } \\
\text { najvišeg } \\
\text { sprata } \\
\text { (sve frekvencije) }\end{array}$} \\
\hline & & \multicolumn{3}{|c|}{ Frekvencija; $\mathrm{Hz}$} & \\
\hline & & $<10$ & $10-50$ & $50-100$ & \\
\hline 1. & $\begin{array}{l}\text { Objekti koji se koriste za zanat- } \\
\text { svo, industrijski objekti i slični. } \\
\text { strukrurni objekti. }\end{array}$ & $20 \times 10^{-3}$ & $\begin{array}{l}20 \times 10^{-3} \\
40 \times 10^{-3}\end{array}$ & $\begin{array}{l}40 \times 10^{-3}- \\
50 \times 10^{-3}\end{array}$ & $40 \times 10^{-3}$ \\
\hline 2. & $\begin{array}{l}\text { Stambene zgrade i po konstrukci- } \\
\text { ji ili nameni slični objekti. }\end{array}$ & $5 \times 10^{-3}$ & $\begin{array}{l}5 \times 10^{-3} \\
15 \times 10^{-3}\end{array}$ & $\begin{array}{l}15 \times 10^{-3}- \\
20 \times 10^{-3}\end{array}$ & $15 \times 10^{-3}$ \\
\hline 3. & $\begin{array}{l}\text { Objekti koji zbog svoje posebne } \\
\text { osetljivosti na vibracije ne spada- } \\
\text { ju u one iz grupe } 1 \text { i } 2 \text {, i koji su } \\
\text { posebno bitni za očuvanje (npr. } \\
\text { nalaze se pod zaštitom kao kul- } \\
\text { turno-istorijski spomenici). }\end{array}$ & $3 \times 10^{-3}$ & $\begin{array}{l}3 \times 10^{-3} \\
8 \times 10^{-3}\end{array}$ & $\begin{array}{l}8 \times 10^{-3}- \\
10 \times 10^{-3}\end{array}$ & $8 \times 10^{-3}$ \\
\hline
\end{tabular}

Tabela 10 Dozvoljene maksimalne prividne brzine oscilovanja

ugroženost objekata od potresa definiše preko koeficijenta potresa $(X)$ (tabela 14), čija je vrednost data jednačinom:

$$
X=\frac{A^{2}}{f}
$$

gde su: $A$ - maksimalna amplituda ubrzanja, $\mathrm{m}$

$$
f \text { - frekvencija, Hz. }
$$

Kriterijum po H. W. Kochu: dinamički uticaj i štetnost potresa procenjuje se preko koeficijenta snage potresa $(S)$, koji se definiše izrazom:

$$
\begin{aligned}
& S=10 \log \left(\frac{x}{x}\right) \quad(14) \\
& \text { gde je: } x_{0} \text {-upporedni pokazatelj potresa za }
\end{aligned}
$$
zgrade, usvaja se da je $x_{0}=0,1 \times 10^{-2} \mathrm{~m} / \mathrm{s}^{2}$.

Vrednosti ovog kriterijuma date su u tabeli 15. 


\begin{tabular}{|c|c|c|c|}
\hline $\begin{array}{l}\text { Vrsta } \\
\text { oštećenja }\end{array}$ & Opis & $\begin{array}{l}\text { Frekvencija } \\
\text { oscilacija, } \mathrm{Hz}\end{array}$ & $\begin{array}{l}\text { Granične brzine }(V r), \\
\mathrm{m} / \mathrm{s}\end{array}$ \\
\hline Estetska & $\begin{array}{l}\text { Pojava tankih prslina u malteru, produ- } \\
\text { ženje i širenje već postojećih prslina u } \\
\text { malteru, nastanak tankih prslina u figu- } \\
\text { rama. }\end{array}$ & $\begin{array}{l}1-4 \\
4-15 \\
15-40 \\
40-300\end{array}$ & $\begin{array}{l}0,45 \times 10^{-2}-1,8 \times 10^{-2} \\
\leq 1,8 \times 10^{-2} \\
1,8 \times 10^{-2}-5 \times 10^{-2} \\
>5 \times 10^{-2}\end{array}$ \\
\hline Mala & $\begin{array}{l}\text { Nastanak većih prslina, ljuštenje i opa- } \\
\text { danje maltera, nastanak prslina na zi- } \\
\text { dovima i betonskim blokovima. }\end{array}$ & $\begin{array}{l}1-4 \\
4-15 \\
15-40 \\
40-300\end{array}$ & $\begin{array}{l}0,8 \times 10^{-2}-4 \times 10^{-2} \\
\leq 4 \times 10^{-2} \\
4 \times 10^{-2}-10 \times 10^{-2} \\
>10 \times 10^{-2}\end{array}$ \\
\hline Veća & $\begin{array}{l}\text { Oštećenja na nosećin elementima, } \\
\text { otvaranje fuga i slično. }\end{array}$ & $\begin{array}{l}1-4 \\
4-15 \\
15-40 \\
40-300-\end{array}$ & $\begin{array}{l}2 \times 10^{-2}-8 \times 10^{-2} \\
\leq 8 \times 10^{-2} \\
8 \times 10^{-2}-20 \times 10^{-2} \\
>20 \times 10^{-2}\end{array}$ \\
\hline
\end{tabular}

Tabela 11 Dozvoljene brzine oscilovanja objekta u funkciji frekvencija

\begin{tabular}{|l|l|l|}
\hline \multirow{2}{*}{ Vrsta oštećenja } & \multicolumn{2}{|l|}{ Brzina oscilovanja $\left(V_{r}\right), \mathrm{m} / \mathrm{s}$} \\
\cline { 2 - 3 } & $2,0-30,0 \mathrm{~Hz}$ & $30,0-300,0 \mathrm{~Hz}$ \\
\hline Bez oštećenja & $0,5 \times 10^{-2}$ & $0,5 \times 10^{-2}-1 \times 10^{-2}$ \\
\hline Lakša oštećenja & $0,5 \times 10^{-2}-2 \times 10^{-2}$ & $1 \times 10^{-2}-5 \times 10^{-2}$ \\
\hline Velika oštećenja & $10 \times 10^{-2}$ & veća od $5 \times 10^{-2}$ \\
\hline
\end{tabular}

Tabela 12 Zavisnost graničnih brzina i očekivanih oštećenja na objektima

\begin{tabular}{|c|c|c|c|c|}
\hline \multirow{3}{*}{$\begin{array}{l}\text { Frekventno } \\
\text { područije }(f), \\
\mathrm{Hz}\end{array}$} & \multicolumn{3}{|l|}{ Objekat na tlu } & \multirow{3}{*}{ Vrsta oštećenja } \\
\hline & Tip “1” & Tip “2” & Tip “3” & \\
\hline & $V_{v}(\mathrm{~m} / \mathrm{s})$ & $V_{v}(\mathrm{~m} / \mathrm{s})$ & $V_{v}(\mathrm{~m} / \mathrm{s})$ & \\
\hline $2,0-10,0$ & $0,4 \times 10^{-2}-1,8 \times 10^{-2}$ & $3,5 \times 10^{-2}$ & $7 \times 10^{-2}$ & \multirow{2}{*}{$\begin{array}{l}\text { Nema vidljivih } \\
\text { pukotina, riseva }\end{array}$} \\
\hline $10,0-50,0$ & $0,6^{*} 10^{-2}-3 \times 10^{-2}$ & $5,5 \times 10^{-2}$ & $11 \times 10^{-2}$ & \\
\hline $2,0-10,0$ & $3 \times 10^{-2}-4 \times 10^{-2}$ & $8 \times 10^{-2}$ & $16 \times 10^{-2}$ & \multirow{2}{*}{$\begin{array}{l}\text { Pojava većih } \\
\text { pukotina }\end{array}$} \\
\hline $10,0-50,0$ & $4 \times 10^{-2}-6 \times 10^{-2}$ & $11,5 \times 10^{-2}$ & $23 \times 10^{-2}$ & \\
\hline
\end{tabular}

Tabela 13 Zavisnost maksimalne vrednosti vertiklane komonente oscilovanja i oštećenja na objektima 


\begin{tabular}{|c|c|c|}
\hline Stepen & Karakteristike oscilacija i ugroženost objekta & Koef. potresa, $(X)$ \\
\hline I & Neosetne & $1-2$ \\
\hline II & Vrlo slabe & $2-10$ \\
\hline III & Slabe - mogu se pratiti prvi risei na malteru i opremi & $10-50$ \\
\hline IV & $\begin{array}{l}\text { Srednje - javljaju se risevi, a mogu nastati i pukotine u } \\
\text { zidovima }\end{array}$ & $50-250$ \\
\hline V & Dosta jake - nastaju risevi i pucaju zidovi, otpada malter & $250-1000$ \\
\hline VI & $\begin{array}{l}\text { Jake - pucanje zidova, armirano-betonske konstrukcije mogu da } \\
\text { padaju }\end{array}$ & $1000-5000$ \\
\hline VII & Vrlo jake - ugrožavaju zgradu mogu ispadati grede, nosači, itd. & $5000-20000$ \\
\hline VII & $\begin{array}{l}\text { Izuzetno jake - neposredno ugrožavaju stabilnost elemenata } \\
\text { konstrukcije pri stalnom delovanju oscilacija. }\end{array}$ & $20000-100000$ \\
\hline
\end{tabular}

Tabela 14 Zellerova skala sa prvih osam stepeni

Analizirajući propise drugih zemalja i na osnovu ličnih iskustava autora (Lit3.) dolazi se do zaključka o uvažavanju sledećeg:

Kada se tlo pobuđuje vibriranjem obavezno registrovati brzine oscilacije (velosigrame).

Opažanja obavezno vršiti sa trokomponentnim senzorom. Detektore orjentisati tako da se registruju dve horizontalne (radijalna i transverzalna) i vertikalna komponenta oscilacije.

Opažanje obavezno vršiti na tlu, na raznim udaljenostima od izvora vibracija (na 1, 5, 10, 20 $\mathrm{m}$ udaljenosti od izvora).

Ako u blizini tačke vibriranja postoji objekat (zgrada) obavezno jedan komplet seizmografa postaviti na temelj objekta, na visinu terena.

Za procenu štetnog delovanja na objekte kao merodavnu veličinu koristiti istinitu rezultantnu brzinu oscilovanja. Ako to nije moguće onda treba koristiti prividnu rezultantnu brzinu oscilacije.

Imajući sve ovo u vidu preporučuje se korišćenje tabele 16 do izrade naših propisa (Lit2.).
Pri izradi ovog rada, pored gore navedenih kriterijuma, koji se u većem broju slučajeva odnose na vibracije izazvane eksplozivom, korišćen je i kriterijum koji je dao ruski istraživač N. V. Koleskin. Njegov kriterijum se zasniva na vrednosti frekvencije date $\mathrm{u} \mathrm{Hz}$ i vrednosti rastojanja krajnjih položaja do kojih čestice pobuđene sredine dopiru u toku jednog oscilatornog ciklusa $(S)$ data u mikronima. On je ove vrednosti predstavio preko dijagrama za procenu opasnosti od vibracija (slika 9).

Pomeranja koja se nalaze ispod dijagrama (1) su bezopasna za objekte, dok su pomeranja iznad krive (2) ta koja prouzrokuju oštećenja. Oblast između ove dve krive predstavlja zonu u kojoj se oštećenja ne očekuju, ali se ne mogu zanemariti [Lit9.]. 


\begin{tabular}{|l|l|l|}
\hline Stepen & Utvrđivanje posledica delovanja & Koeficijent, $(S)$ \\
\hline I & Potres - koji se ne oseća na objektu & do 10 \\
\hline II & Slabi potresi - bez oštećenja objekata & $10-20$ \\
\hline III & $\begin{array}{l}\text { Srednji potresi - bez značajnih oštećenja građevina, prvi risovi i na- } \\
\text { puknuća }\end{array}$ & $20-30$ \\
\hline IV & $\begin{array}{l}\text { Dosta jak potres - dolazi do oštećenja građevina, pucanja zidova, ot- } \\
\text { padanja maltera }\end{array}$ & $30-40$ \\
\hline V & $\begin{array}{l}\text { Jaki potresi - velike štete na građevinama, pucanje zidova, ugrožava- } \\
\text { nje stabilnosti građevine }\end{array}$ & $40-50$ \\
\hline VI & $\begin{array}{l}\text { Veoma jaki - potresi koji uzrokuju havarije i mogućnost potpunog } \\
\text { uništenja nekih građevina. }\end{array}$ & $50-60$ \\
\hline
\end{tabular}

Tabela 15 Skala sa opisom karakteristika oscilacija

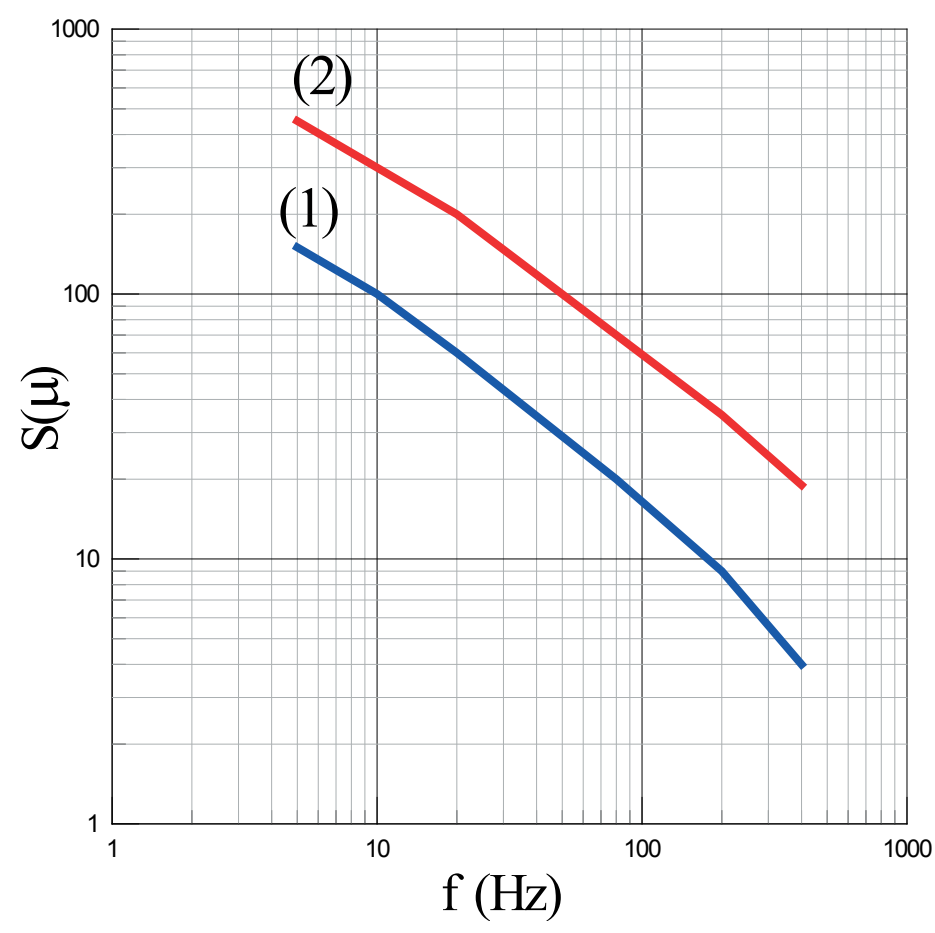

Slika 9 Promena razmaha pomeranja u zavisnosti od frekvencije 


\begin{tabular}{|l|c|}
\hline \multicolumn{1}{|c|}{ Vrsta oštećenja } & Granična brzina, $\mathrm{m} / \mathrm{s}$ \\
\hline Štete nisu verovatne & $\leq 0,5 \times 10^{-2}$ \\
\hline Štete malo verovatne & $0,5 \times 10^{-2}-1,8 \times 10^{-2}$ \\
\hline Štete verovatne & $1,8 \times 10^{-2}-10 \times 10^{-2}$ \\
\hline Štete sigurno nastaju & $\geq 10 \times 10^{-2}$ \\
\hline
\end{tabular}

Tabela 16 Zavisnost vrste oštećenja objekta i granične brzine ocilovanja

\section{IZVEDENA GEOFIZIČKA MERENJA}

U cilju utvrđivanja nivoa mikrovibracija koje deluju na arheološki lokalitet, izvršen je namenski monitoring mikrotremora. Pri ovome se težilo utvrđivanju mikrovibracija koje su izazvane radom termoelektrane "Kostolac B". Na slici 10 su zelenim okvirima prikazane zone osmatranja mikrovibracija. U gornjem levom okviru su tačke na kojima je vršeno osmatranje vezano isključivo za termoelektranu.

\section{ZONA UTICAJA TERMOELEKTRANE "Kostolac B"}

Osmatranje mikrotremora, vezano za termoelektranu kao izvora vibracija (na slici 11), izvedeno je na 41 tački koje su bile locirane duž pojedinih profila (na slici 12).

Da bi se obezbedili bolji reziltati dobijeni osmatranjem i analizom mikrotremora, potrebno je smanjiti proizvoljni uticaj njihovih pobuda i povećati njihovu funkcionalnu zavisnost od lokal-

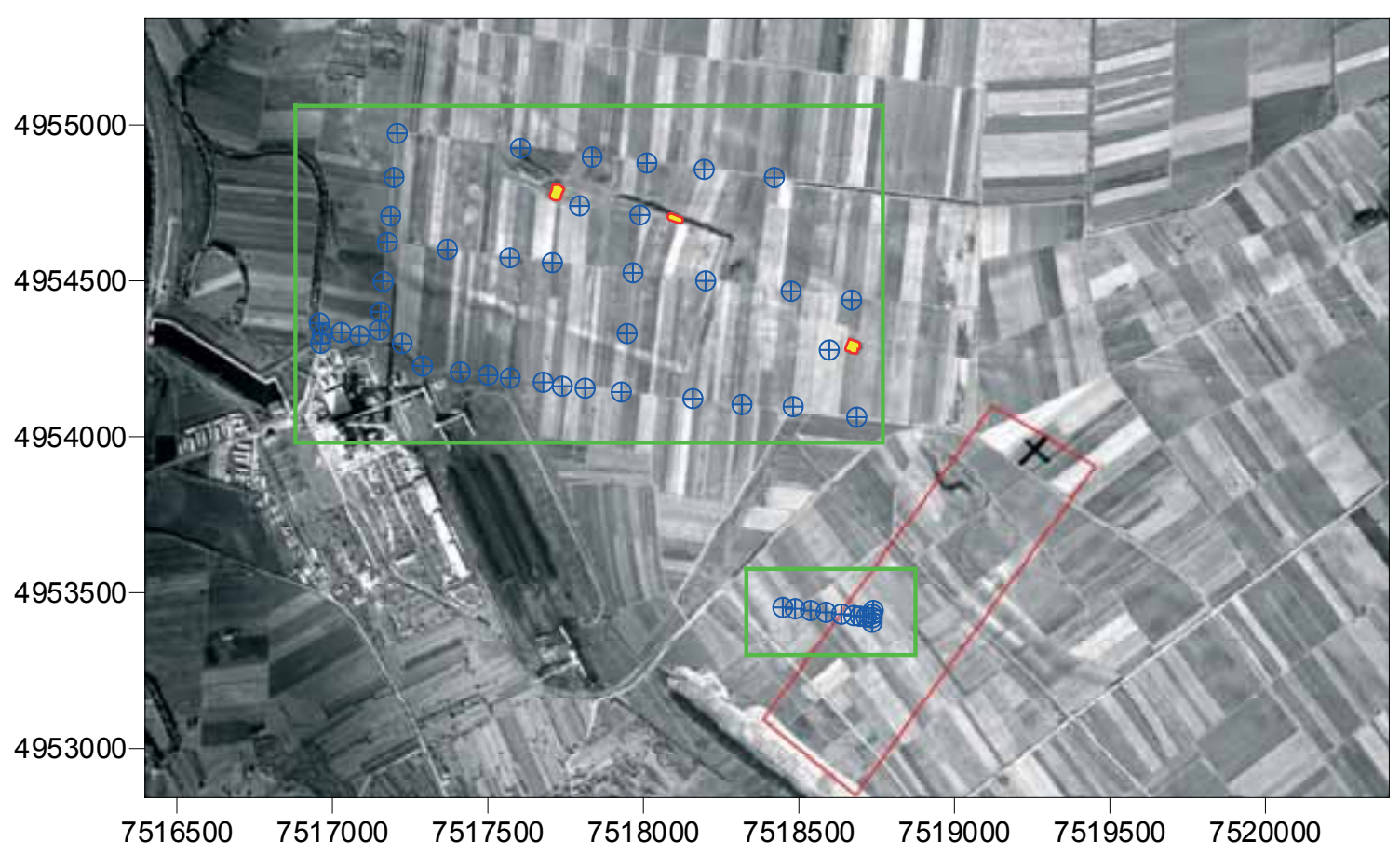

Slika 10 Raspored tačaka osmatranja mikrotremora 


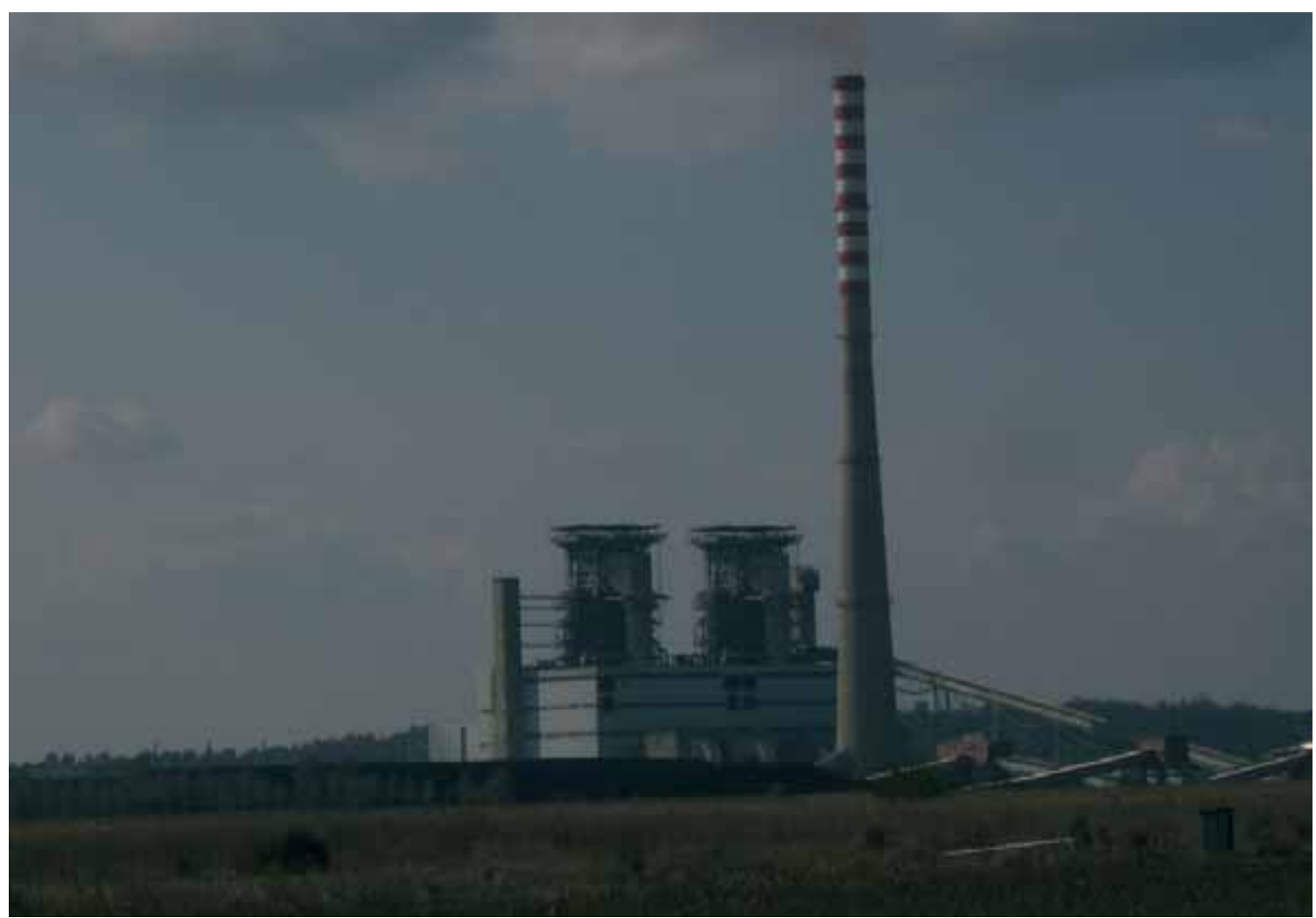

Slika 11 Termoelektrana Kostolac B snimljena iz zone Viminaciuma

nih svojstava oscilovanja poluprostora. To je postignuto upotrebom osetljivih senzora za njihovo registrovanje i primenom naprednih softvera za analizu njihovog spektra.

Brzina uzorkovanja iznosila je 400 uzoraka u sekundi, što znači da je period semplovanja 2,5 ms. Tačke su raspoređene duž puteva i oko otkrivenih arheoloških lokaliteta (predstavljeni zutom bojom u plavom okviru na slici 12). Pri tome se težilo utvrđivanju zavisnosti uticaja mikrovibracija od udaljenosti termoelektrane koja je njihov stalni izvor.

\section{OBRADA PODATAKA I INTERPRETACIJA}

Nakon završenog monitoringa mikrovibracija, svi podaci su obrađeni u programu Surfer, (Golden Software). Pored vrednosti brzina oscilovanja vezanih za X, Y i Z osu koje su prikupljene na terenu, izvršen je i proračun vrednosti horizontalnog $(\mathrm{H})$ i totalnog $(\mathrm{T})$ vektora, koje su dalje analizirane. Ovi vektori su dobijeni po sledećim formulama

$$
\begin{gathered}
H=\frac{Y}{\cos \left(\operatorname{arctg} \frac{X}{Y}\right)} \\
T=\frac{H}{\cos \left(\operatorname{arctg} \frac{Z}{H}\right)}
\end{gathered}
$$

gde su: $\mathrm{X}$ - podaci osmatranih mirovibracija u pravcu $\mathrm{X}$ ose

bracija u pravcu $Y$ ose

$\mathrm{Y}$ - podaci osmatranih mikrovi-

$\mathrm{Z}$ - podaci osmatranih mikrovi-

bracija u pravcu $\mathrm{Z}$ ose.

Zbog velikog broja podataka bazne vrednosti neće biti prikazane u ovom radu. Podaci su u programu GeoDas, brzom Furijevom transformacijom (FFT) razloženi na odovarajuće spektre. Sa spektra svakog signala, izdvajani su maksimalni pikovi (amplitude relativnih vrednosti brzina osmatranih mikrovibracija), kao i frekvencije na kojima se oni nalaze.

Podaci su posle izvršene analize spektra i statistički obrađeni. Statistička obrada je vršena 


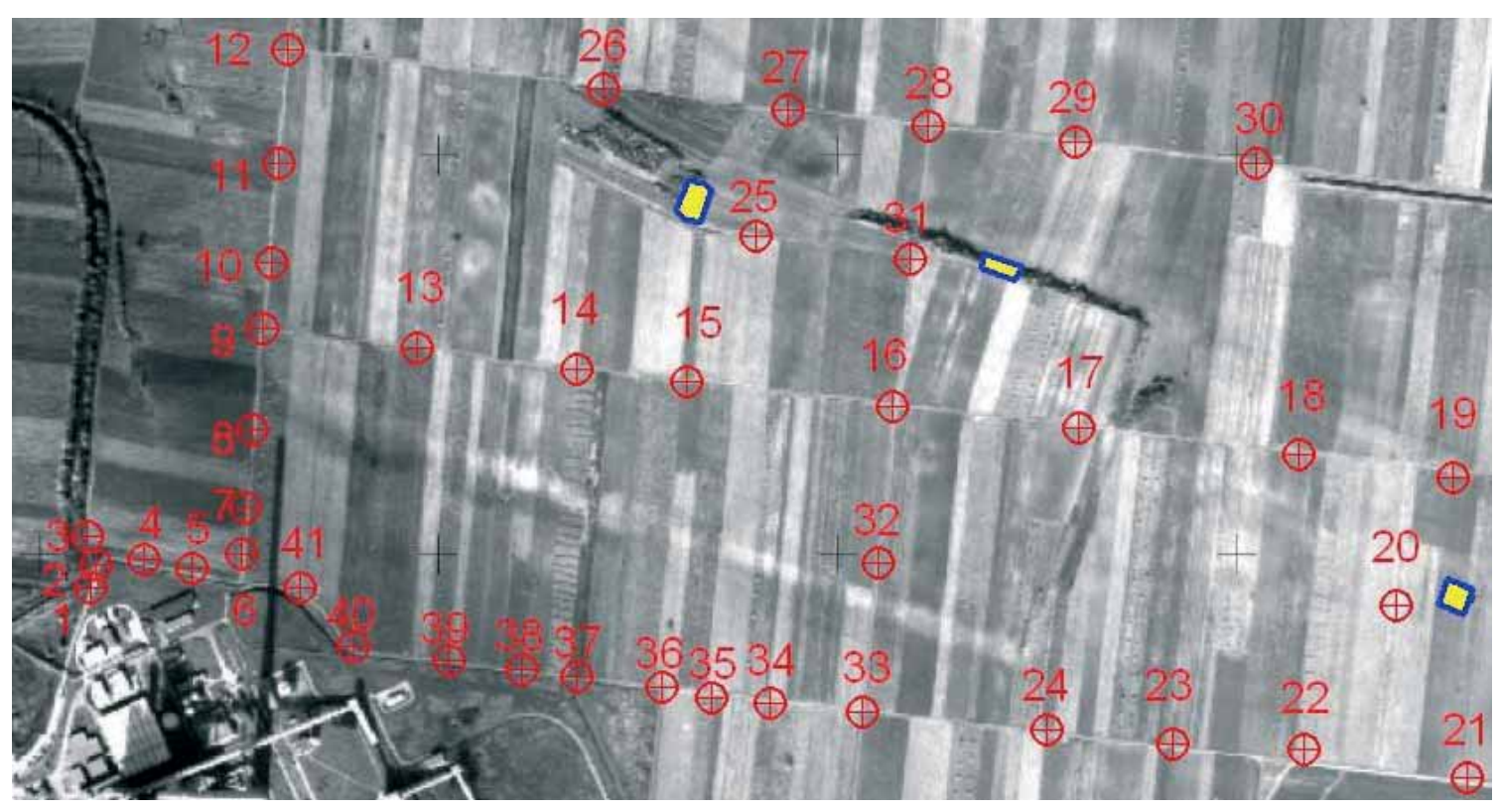

Slika 12 Raspored tačaka osmatranja mikrotremora u zoni uticaja termoelektrane

u okviru određenih prozora frekvenci radi lakšeg sagledavanja rasporeda pikova koji su nosioci energije osmatranih mikrotremora u okviru pojedinih frekventnih opsega.

U daljem delu teksta prikazana je slika signala svih komponenata. Pri izradi ove slike odabrana je po jedna tačka iz obe zone osmatranih mikrovibracija. Ove tačke su uzete kao reprezentativne pri obradi dobijenih vrednosti.

Prvo je prikazan signal tačke MT6 koja se odnosi na zonu uticaja termoelektrane (slika 13 a i b), po X, Y, Z, H i T komponenti. Na slici 13 a su prikazani zajedno snimljeni signali za X, Y i Z komponente, dok na slici $13 \mathrm{~b}$ imamo prikazane signale $\mathrm{H}$ i $\mathrm{T}$ komponente.

$\mathrm{Na}$ ovim slikama pored signala iscrtani su i naznačeni prozori po kojima je vršena analiza signala. Analiza po prozorima je vršena radi lakšeg sagledavanja pikova kao i njihovih frekvencija. Kod osmatranih tačaka u zoni termoelektrane korišćena su tri prozora i to: od $6 \mathrm{~Hz}$ do $9 \mathrm{~Hz}$, od $10 \mathrm{~Hz}$ do $14 \mathrm{~Hz}$ i od $16 \mathrm{~Hz}$ do $18 \mathrm{~Hz}$, koji se vide na slikama. Izdvojeni prozori su bez preklapanja, jer na ovim signalima imamo jasno izdvajanje pikova. Vidi se da širine prozora nisu jednake, tj. oni nemaju iste vrednosti frekvencija. Prvi prozor je prozor najnižih frekvencija i tu se nalazi prvi pik mikrovibracija, dok je drugi prozor nešto širi. Treći prozor je i najuži i u njemu se javlja karakteristični treći pik. Takođe, sa slike vidimo i da se posle trećeg prozora javljaju pikovi, ali su ovo najverovatnije multipli predhodnih pikova; pa iz tih razloga nisu posebno izdvajani.

Posle analize signala podaci su statistički obrađeni i izdvojene su vrednosti maksimuma amplituda, opsega frekvencija, medijana, standardne devijacije i relativne energije kao količnika sume amplituda i opsega frekvencija. I ovde su svi podaci obrađeni po X,Y i Z osi i H i T vektoru.

\section{OBRADA I PRIKAZ PODATAKA UTICAJA TERMOE- LEKTRANE "KostolaC B"}

Osmatranjem u okolini termoelektrane težilo se utvrđivanju nivoa mikrovibracija i definisanju funkcionalne zavisnosti mikrovibracija sa udaljavanjem od njihovog izvora. Rasporedom tačaka osmatranja obuhvaćeni su i otkriveni arheološki lokaliteti: Terme - koje su najbliže termoelektrani, Severna kapija i Mauzolej koji se nalazi na granici istražnog područja. U daljem tekstu će biti prikazan deo tabele u kojoj se nalaze podaci o vrednosti pika za X, Y i Z osu kao i relativne energije za H i T vektor (tabela 17). Ovi podaci su dobijeni analizom po segmentima opisanoj u predhodnom poglavlju i predstavljaju relativne vrednosti za tri tačke osmatranja mikrovibracija.

U tabeli je dat prikaz tri tačke osmatranja i to po prethodno navedenim prozorima od 6-9, od 


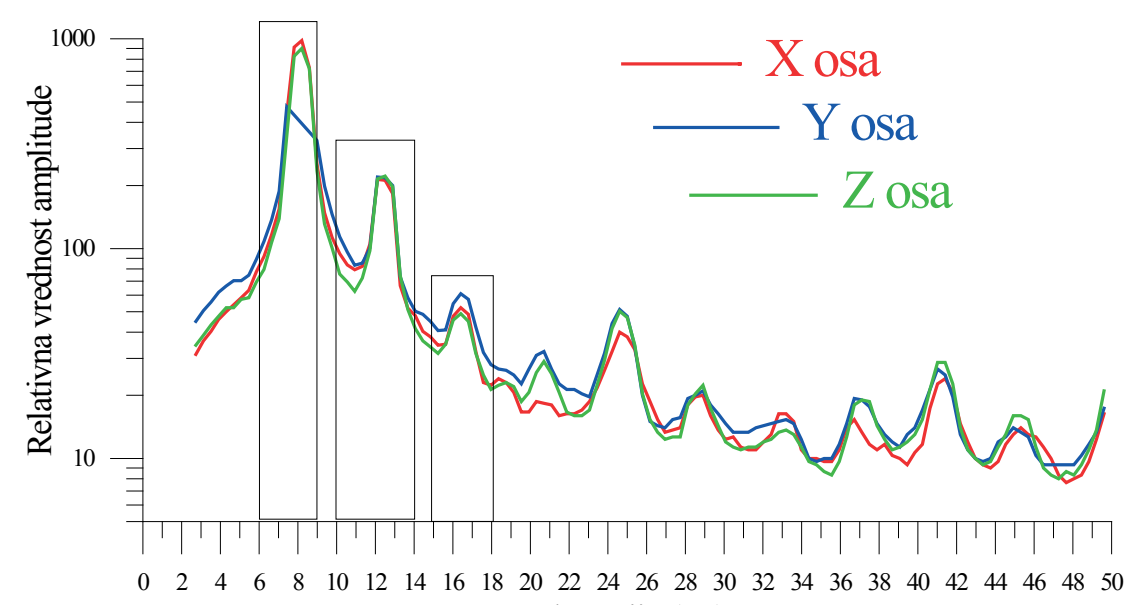

Frekvencija $(\mathrm{Hz})$

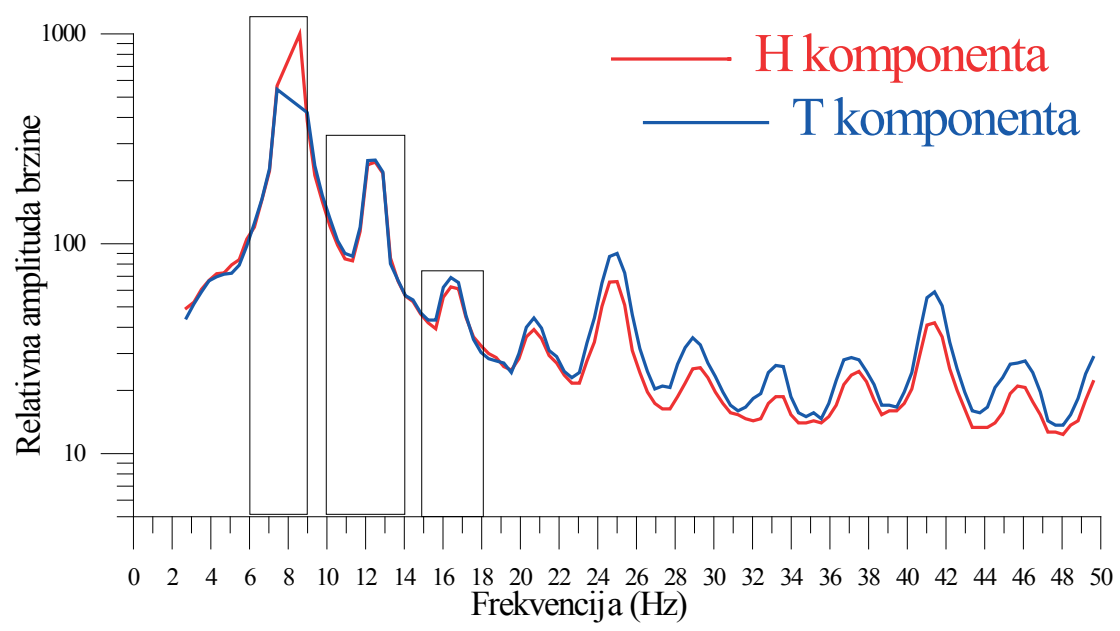

Slika 13 Prikaz signala posle izvršene FFT analize za MT 6: a-X,Y i Z osa, b-H i T komponenata

10-14 i od 15-18 HZ, čiji podaci se nalaze u prve dve kolone. U daljem delu tabele unete su vrednosti prva dva pika po osmatranim osama. Prvi pik je odabran jer je on nosilac najvećeg dela energije, dok drugi pik po vrednosti ne odstupa mnogo od prvog, ali je nosilac manje količine energije. Iz ove tabele se vidi da se prvi pikovi u svim slučajevima nalaze u prvom prozoru, tj. na nižoj frekvenciji. Poslednje dve kolone daju vrednosti relativnih energija za horizontalni i totalni vektor. Iz tabele se vidi da su, takođe, najviše vrednosti energije skoncentrisane baš u prvom prozoru, tj. prate vrednost maksimalnog pika. Iz priloženih podataka se vidi da tačka osmatranja MT1 ima najveće vrednosti pika, kao i relativnih energija, jer je najbliža izvoru mikrovibracija u odnosu na ostale dve.

U daljoj obradi podataka na osnovu vrednosti za sve tačke, izrađene su karte koje pokazuju distribuciju maksimalnih vrednosti Z, H i T komponente kao i kartu sferne disperzije. Prvo su izrađene karte rasporeda prvih pikova (slika 14 a, b, c). Radi boljeg sagledavanja distribucije prvog pika na ovoj slici su prikazane karte sve tri komponente. To omogućava lakše tumačenje rasporeda prvih pikova na osmatranim tačkama.

Posmatrajući sve tri karte vidi se da se maksimalne vrednosti javljaju u jugozapadnom delu gde su tačke osmatranja najbliže termoelektrani. Primećuju se dva maksimuma na tačkama MT4 i MT6, dok je na karti Z pika maksimum na MT4 manje izražen nego kod H i T pika. Uda- 


\begin{tabular}{|c|c|c|c|c|c|c|c|c|c|}
\hline \multirow{2}{*}{$\begin{array}{c}\text { Naziv } \\
\text { tačke }\end{array}$} & Prozori & $\begin{array}{c}\text { X } \\
\text { pik I }\end{array}$ & $\begin{array}{c}\text { X } \\
\text { pik II }\end{array}$ & $\begin{array}{c}\text { Y } \\
\text { pik I }\end{array}$ & $\begin{array}{c}\text { Y } \\
\text { pik II }\end{array}$ & $\begin{array}{c}\text { Z } \\
\text { pik I }\end{array}$ & $\begin{array}{c}\text { Z } \\
\text { pik II }\end{array}$ & $\begin{array}{c}\text { H } \\
\text { relativna } \\
\text { energija }\end{array}$ & $\begin{array}{c}\text { T } \\
\text { relativna } \\
\text { energija }\end{array}$ \\
\hline \multirow{2}{*}{ MT1 } & $6-9$ & 1285.9 & & 1131.9 & & 913.5 & & 771.76 & 835.65 \\
\cline { 2 - 10 } & $10-14$ & & 305.1 & & 405.9 & & 242.9 & 269.62 & 268.74 \\
\cline { 2 - 10 } & $15-18$ & & & & & & & 147.63 & 145.88 \\
\hline \multirow{2}{*}{ MT2 } & $10-14$ & & 301.6 & & 332.8 & & 380.5 & 396.11 & 422.82 \\
\cline { 2 - 10 } & $15-18$ & & & & & & & 207.17 & 190.06 \\
\hline \multirow{2}{*}{ MT3 } & 610 & & 603.8 & & 585 & & 752.93 & 774.98 \\
\cline { 2 - 10 }$y$ & $10-14$ & & 409.2 & 522.1 & & 450.4 & & 382.83 & 437.7 \\
\cline { 2 - 10 }$y$
\end{tabular}

Tabela 17 Analiza mikrovibracija po segmentima

ljavanjem od same termoelektrane dolazi do manje-više zonarnog opadanja vrednosti. Takođe, se primećuje da na tački osmatranja MT5 dolazi do pojave povećane vrednosti prvog pika, kao i kod tačke MT33, što je najverovatnije uslovljeno litološkim karakteristikama terena.

Pojave rasta vrednosti na sve tri karte postoje u pravcu severa od tačke MT6 ka MT12, kao i u pravcu juga od tačke MT6 ka MT37. Pored ovih povećanih vrednosti primećuje se i minimum vrednosti oko MT35, gde opet litologija najverovatnije utiče na raspored vrednosti mikrovibracija. Od arheoloških lokaliteta Terme su najbliže termoelektrani kao izvoru mikrovibracija pa su prema tome najviše njima i izložene. Za razliku od ovog lokaliteta Mauzolej je najudaljeniji od izvora, pa je prema tome on u zoni manjih vrednosti prvog pika.

Posle razmatranja rasporeda vrednosti prvog pika treba obratiti pažnju na distribuciju drugog pika kod Z, H i T komponente (slika 15 a, b, c). Ovaj pik nosi nešto manje energije u odnosu na prvi. Posmatrajući tabelu u Prilogu 1 vidi se da su u većini slučajeva vrednosti drugog pika nešto manje od vrednosti prvog pika. Ovi podaci se nalaze najčešće $u$ drugom prozoru tj. $u$ opsegu frekvencija od 10 do $14 \mathrm{~Hz}$. To ukazuje da se ovaj pik nalazi u podređenom delu spektra u odnosu na prvi pik.

Kod karata distribucije drugog pika vide se maksimalne vrednosti nešto šire rasprostranjene nego u prethodnom slučaju. I dalje je ta vrednost na jugozapadno delu karte, što je i očekivano, jer je taj deo najbliži izvoru osmatranih vibracija. Iako je ovde reč o rasprostranjenijem pojasu uticaja drugog pika, ipak je on po svojoj vrednosti manji od vrednosti prvog pika (maksimum prvog pika je na oko 2800 dok je vrednost maksimuma drugog pika na oko 720).

Na karti Z komponenete maksimum je na tačkama osmatranja MT40 i MT39, kao i u zoni MT3. Na druge dve karte maksimumi se podudaraju u zoni tačaka MT40 kao i zoni tačaka MT4 i MT5. Ovde se javlja rast vrednosti u pravcu severa od tačke MT6 ka tački MT12, kao i u pravcu juga od MT6 ka MT37. Posmatrajući kartu T pika vidi se da pored osnovnih putanja rasta vrednosti postoji i rast vrednosti u pravcu severoistoka od MT41 ka MT36. Takođe, na karti Z komponente vidi se porast vrednosti drugog pika oko tačke MT17.

Ovi pravci rasta vrednosti drugog pika sa 

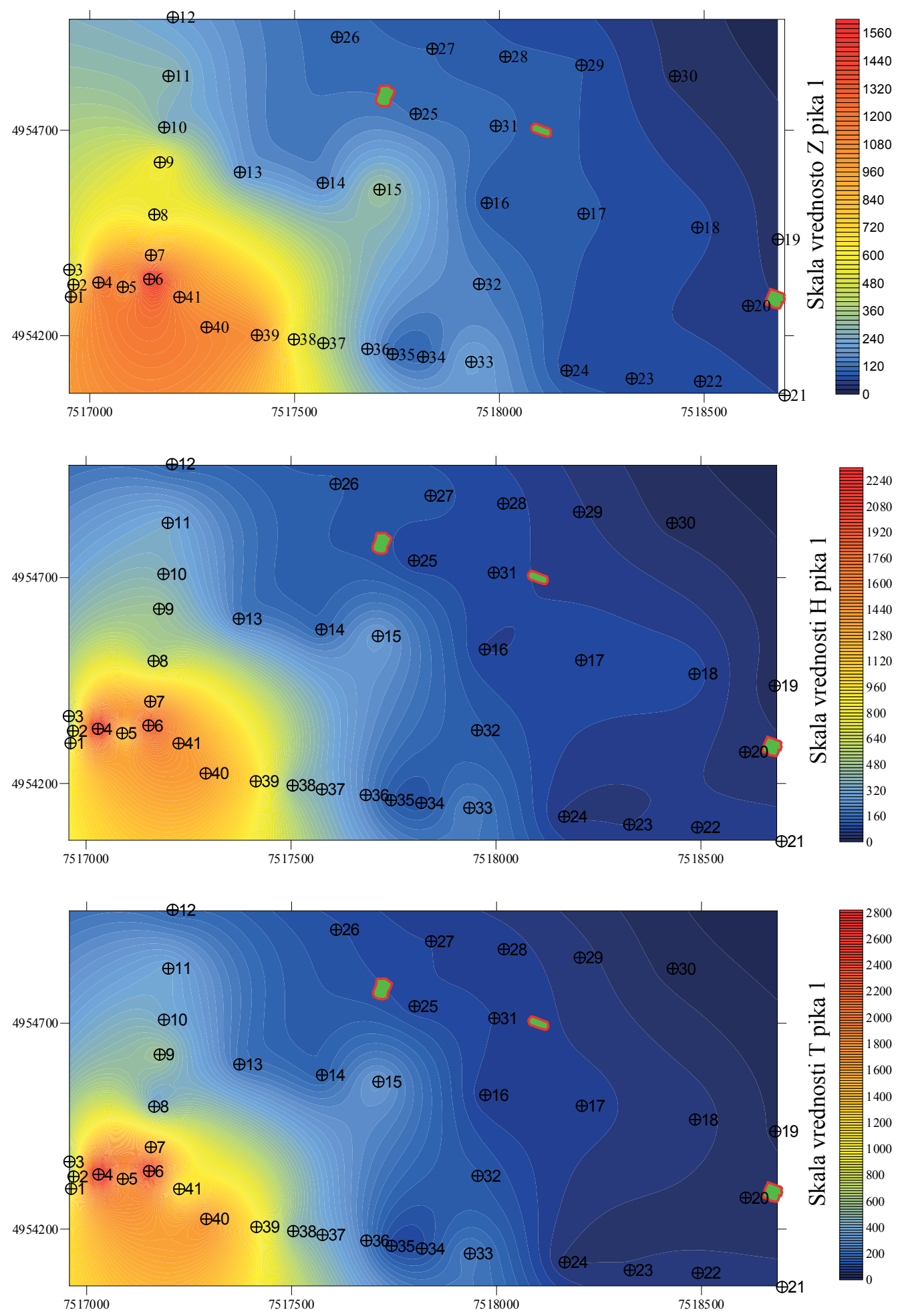

Slika 14. Raspored vrednosti prvog pika: a - Z komponente, b - H komponente i c - T komponente 

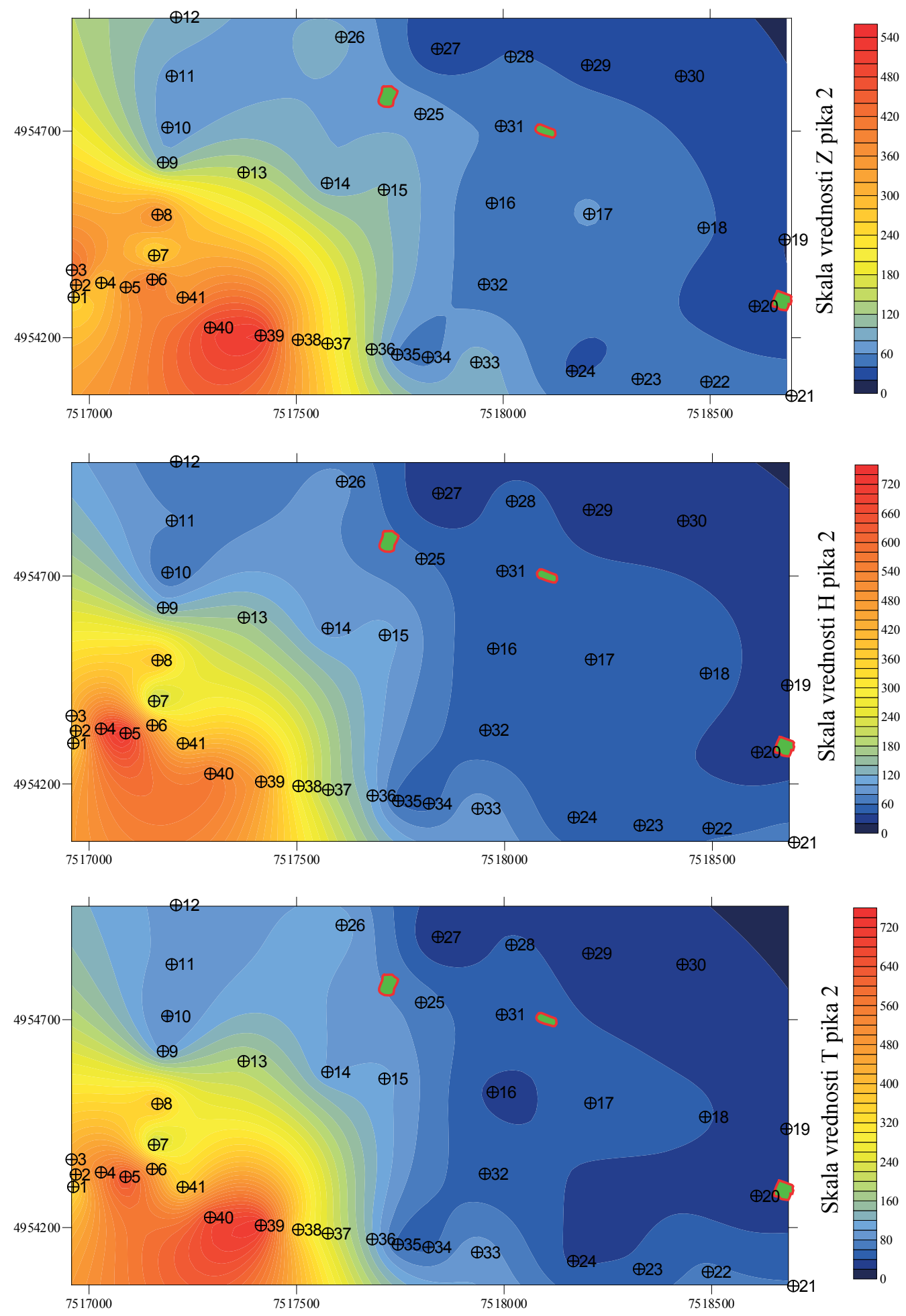

Slika 15. Raspored vrednosti drugog pika: a - Z komponente, b - H komponente i c - T komponente 
udaljavanjem od termoelektrane su najverovatnije uslovljeni litologijom osmatranog terena. Minimalne vrednosti se na sve tri karte javljaju na krajnjem istočnom i severoistočnom delu, mada postoje pojave minimuma na sve tri karte oko MT35, kao i oko MT16 na karti distribucije H pika, i MT24 na karti Z komponente. Ovde je lokalitet Termi u zoni jačeg uticaja drugog pika u odnosu na predhodni slučaj, dok je Mauzolej i dalje u polju malih vrednosti.

Po završenom modelovanju i analizi podataka po pikovima izvršena je analiza distribucije relativne energije H i T komponente. Ovde je energija predstavljena po unapred opisanim prozorima. Distribucija energije je prikazana samo za ove dve komponente, jer posmatrajući formulu (15) one najbolje odražavaju sliku svih vrednosti. Kao što se vidi po formulama za definisanje $\mathrm{H}$ i T vektora koriste se vrednosti sve tri komponenete osmatrane na terenu, tako da one predstavljaju njihov zbirni uticaj. Pri prikazivanju ovih vrednosti krenulo se od prozora sa najnižim, ka prozoru sa najvećim frekvencijama i to odvojeno za $\mathrm{H}$ (slika $16 \mathrm{a}, \mathrm{b}, \mathrm{c})$, pa zatim i za T komponentu.

Sa izrađenih karata se vidi da je najveća količina energije skoncentrisana u prvom prozoru, gde su najniže vrednosti frekvencija, i da opada idući ka višim frekvencijama. Maksimumi su i dalje skoncentrisani na jugozapadu. Kod prve karte koja se odnosi na prozor od 4 do $8 \mathrm{~Hz}$, maksimum je skoncentrisan oko tačaka MT6 i MT41. Na druge dve karte postoje dve izdvojene zone maksimuma i to oko tačaka MT5 i MT40. Energije u sva tri prozora i dalje zadržavaju pravac povećanja vrednosti ka severu i jugu, mada se ovde kod energije u opsegu od 9 do $14 \mathrm{i}$ od 15 do $18 \mathrm{~Hz}$ uočava i pravac povećanja od MT40 do MT15. Sa karata se vidi da su sva tri arheološka lokaliteta u zoni uticaja visoke energije u prvom prozoru, dok su u ostalim prozorima pod manjim uticajem, što je logično jer su i energije manje.

Po navedenim prozorima analizirana je $\mathrm{i}$ distribucija relativne energije, za $\mathrm{T}$ komponentu (slika 17 a, b, c). Ove karte kao i karte distribucije relativne energije $\mathrm{H}$ komponente ukazuju da je najveća energija skoncentisana u prvom prozoru tj. u zoni najmanjih frekvencija od 4 do $8 \mathrm{~Hz}$ gde su skoncentrisani i prvi pikovi X, Y i Z komponenata. Maksimum i u ovom slučaju je u jugozapadnom delu istražnog terena. Njegovo rasprostiranje je nešto veće $u$ okviru poslednja dva prozora $u$ odnosu na prvi, ali su vrednosti tih maksimuma znatno manje. Na prvoj karti maksimum je u zoni tačke osmatranja MT6, dok na drugoj postoje dva izdvojena maksimuma u okolini MT40 i MT5. Na poslednjoj se opet izdvaja jasan maksimum kod tačke MT40. Kod distribucije energije T komponente postoje pravci rasta vrednosti ka severu i jugu, kao i ka severoistoku od MT40 do MT15 na poslednjoj karti. Na ovoj karti se javlja i minimalna vrednost na MT16 što je najverovatnije uslovljeno litologijom terena.

Posle obrade i interpretacije karata i vrednosti pikova i energija po izdvojenim prozorima izrađena je karta sferne disperzije (slika 18). Pri njenoj izradi krenulo se od pretpostavke da je reč o homogeno uslojenoj sredini kao i tačkastom izvoru mikrovibracija, kako bi se formirao model čistog uticaja mikrovibracija termoelektrane na ispitivani deo terena.

Ova karta predstavlja modelovanu funkciju raspodele energije od njenog izvora. Ovde je izvor prikazan zelenom tačkom na jugozapadnom delu karte. Na njoj se zapaža koncentrično kretanje srednjih vrednosti energije s obzirom da se kao osnova uzeo homogen, izotropan poluprostor i tačkasti izvor. Maksimum energije je i ovde u jugozapadnom delu karte. Vidi se i da sa udaljavanjem od izvora dolazi i do postepenog pada vrednosti energije. Svaka oblast na karti je izdvojena u zasebne zone koje se odlikuju određenom vrednosti energije tačkastog izvora. Na osnovu ove karte formirane na bazi homogenog i izotropnog poluprostora vršene su analize raspodele pikova i energije koje su prethodno opisane. Od svih tih navdenih vrednosti oduzeta je sferna disperzija i proračunate su karte koje pokazuju lokalne anomalne zone. Na ovakvim kartama se uočava uticaj litologije terena na raspored vrednosti mikrotremora.

Prvo su upoređene karte prvog pika sa kartom sferne disperzije (slika 19 a, b, c). Ovim upoređivanjem može se videti gde karakteristike ispitivanog poluprostora najviše utiču na distribuciju prvog pika kod sve tri komponente.

Posmatrajući prikazane karata razlike vrednosti prvog pika uviđa se da su se maksimalne zone i dalje zadržale u jugozapadnom delu karte. Primećuje se i da su vrednosti $Z$ komponente mnogo manje u odnosu na ostale. To ukazuje na to da litološka 
građa terena najviše utiče na rasprostriranje $\mathrm{Z}$ prvog pika. Vidi se i da na prvoj karti postoje oblasti minimalnih vrednosti oko tačke MT35, kao i veće vrednosti oko MT15 i MT39, gde opet do izražaja dolazi litologija terena. Takođe, se pojavljuju i dve nešto šire oblasti povećanih vrednosti na severoistoku u okolini lokaliteta Severne kapije. Što se tiče karata $\mathrm{H}$ i $\mathrm{T}$ komponente tu nema neke veće razlike posle oduzimanja karte sferne disperzije. Na sve tri karte oko tačake MT35 vidimo minimalne vrednosti mikrovibracija Ovde se primećuje manji uticaj litološke građe na $\mathrm{H}$ i T prvi pik u odnosu na $\mathrm{Z}$ pik.

Posle analize uticaja litologije terena na rasprostiranje prvog pika prelazi se na analizu uticaja litologije na drugi pik sve tri komponente (slika. 20 $\mathrm{a}, \mathrm{b}, \mathrm{c})$. Kao što će se videti na priloženim kartama ovde karakteristike istraživanog poluprostora imaju veći uticaj na širenje mikrovibracija, tj. njihovih drugih pikova. Ovi drugi pikovi, kao što je već ranije istaknuto odlikuju se višim frekvencijama, ali su nosioci nešto manje relativne energije $u$ odnosu na prve pikove.

Sa slike se jasno vide zone maksimalnog uticaja litološke građe u oblasti tačke MT39. Ovo se objašnjava mogućnosti da postoji greben $u$ toj zoni koji prigušuje mikrovibracije. Najmanji uticaj karakteristike terena imaju na pik $\mathrm{T}$ komponente. Takođe,se vidi da su u samom jugozapadnom delu, gde su maksimalne vrednosti mikrovibracija, uticaji litološke građe najmanji. To se i očekivalo, jer je izvor mikrovibracija u blizini. Ovde se jasno izdvajaju zone predstavljene žutom do svetlo narandžastom bojom oko tačaka MT11 preko MT15 ka MT24 koje su nosioci male razlike vrednosti. To ukazuje da oko lokaliteta Severne kapije i Terme litologija nema većeg uticaja na prigušenje vibracija.

Pri analizi uticaja litološke građe na relativne energije H i T komponente od karata vrednosti rasprostiranja energija za naznačene komponente oduzimana je odgovarajuća karta vrednosti za model sferne disperzije. Time su dobijene lokalne anomalije koje potvrđuju da na distribuciju energije mikrovibracija utiče i građa ispitivanog terena. Prvo se kao i u predstavljanju relativnih energija krenulo od H komponente (slika 21 a, b, c)

Posmatrajući karte na slici 21 odmah se uočava da je najmanja razlika na karti energije u prvom prozoru koji ima opseg frekvencija od 4 do $9 \mathrm{~Hz}$. Karte distribucije energije druga dva prozora su znatno izmenjene. Najmanji uticaj litološke građe je i ovde u zoni najbližoj izvoru. Na kartama energije se, takođe, izdvaja greben koji i dalje ima veliki uticaj na smanjenje distribucije energije $\mathrm{H}$ komponente. Greben se i ovde izdvaja maksimalnom vrednošću označenom crvenom bojom, kao i u predhodnim slučajevima.

Jasno se vidi i da se uticaj litološke građe povećava sa povećanjem frekventnog opsega mikrovibracija. Njen najveći uticaj se primećuje na karti trećeg prozora koji je nosilac i najvećih frekvencija od 15 do $18 \mathrm{~Hz}$.

Tumačenje uticaja geološke građe na prostiranje relativne energije $\mathrm{T}$ komponente (slika 22 a, b, c), je izneta u odvom delu diplomskog rada. Sa narednih karata primećuje se da je uticaj litološke građe na energije ove komponente sličan kao i kod vrednosti H energije. Ovde se primećuje najmanja izmena na karti relativne energije u prozoru od 6 do $9 \mathrm{~Hz}$. Promene se povećavaju sa povećavanjem vrednosti frekvencije u prikazanim prozorima, pa je i u ovom slučaju najveća promena na trećoj karti koju odlikuju i najveće vrednosti. I dalje postoji jasno izdvajanje grebena u oklini tačke MT38 i MT39. Najmanja izmena vrednosti energije je u jugozapadnom delu koji je i najbliži izvoru vibracija, i udaljavanjem od njega promene u distribuciji relativnih energija su sve primetnije.

Nijedan istraživan teren nije homogen $\mathrm{i}$ izotropan pa zbog toga se ne može imati ni ovde koncentrično i jasno izdvajanje zona uticaja mikrovibracija. Sa slika se vidi da litološka građa ima najmanji uticaj u slučajevima prvih pikova i prvih prozora, jer se njihovi frekventni domeni poklapaju i odgovaraju nižim frekvencijama. Porastom vrednosti frekvencija mikrovibracije su više izložene uticaju geološke građe, pa su iz tog razloga karte razlike relativnih energija najviše izmenjene oduzimanjem sferne disperzije. 

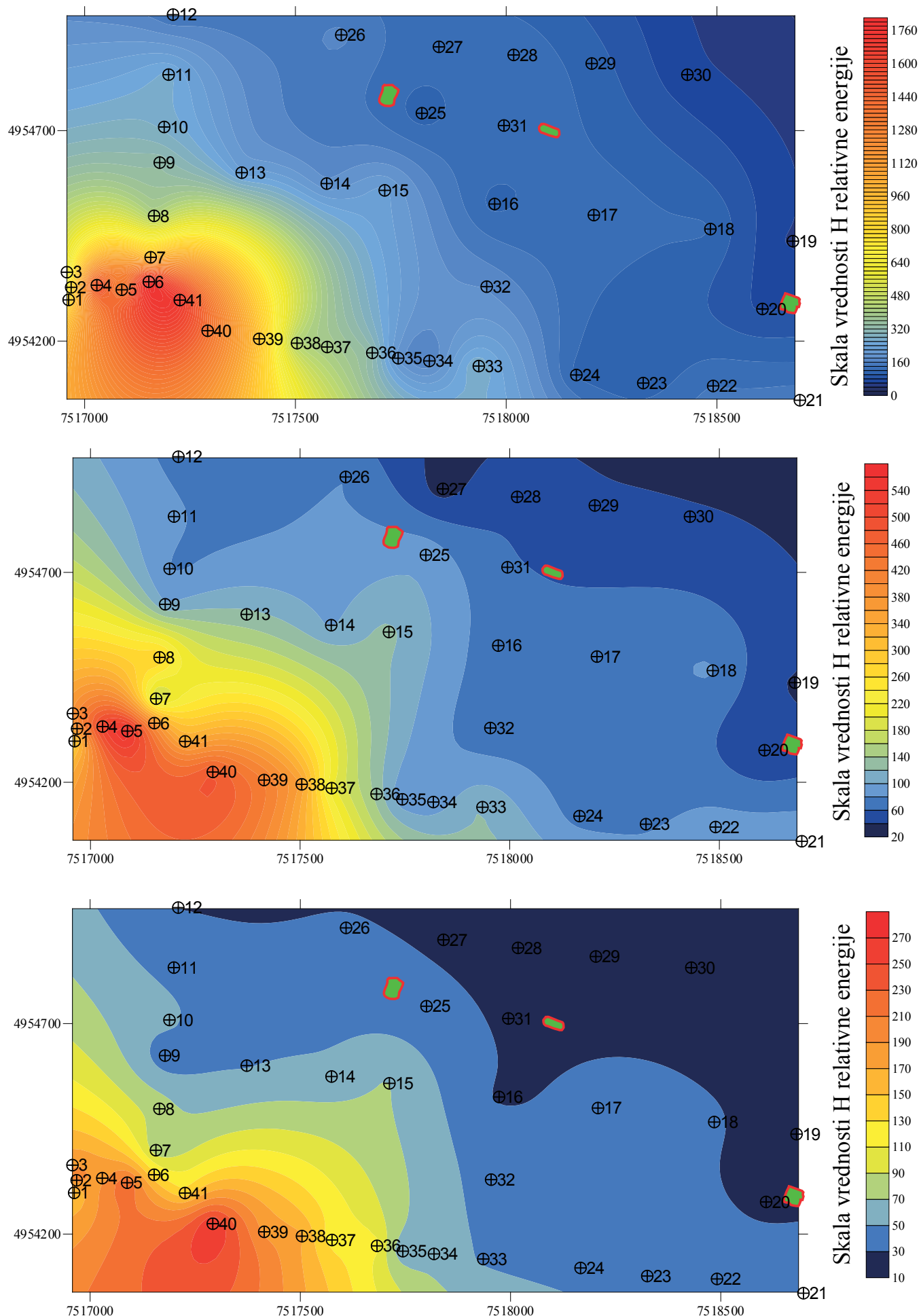

Slika 16. Raspored relativnih energija H komponente: a- od 6 do 9 , b-od 10 do 14 i c- od 15 do $18 \mathrm{~Hz}$ 

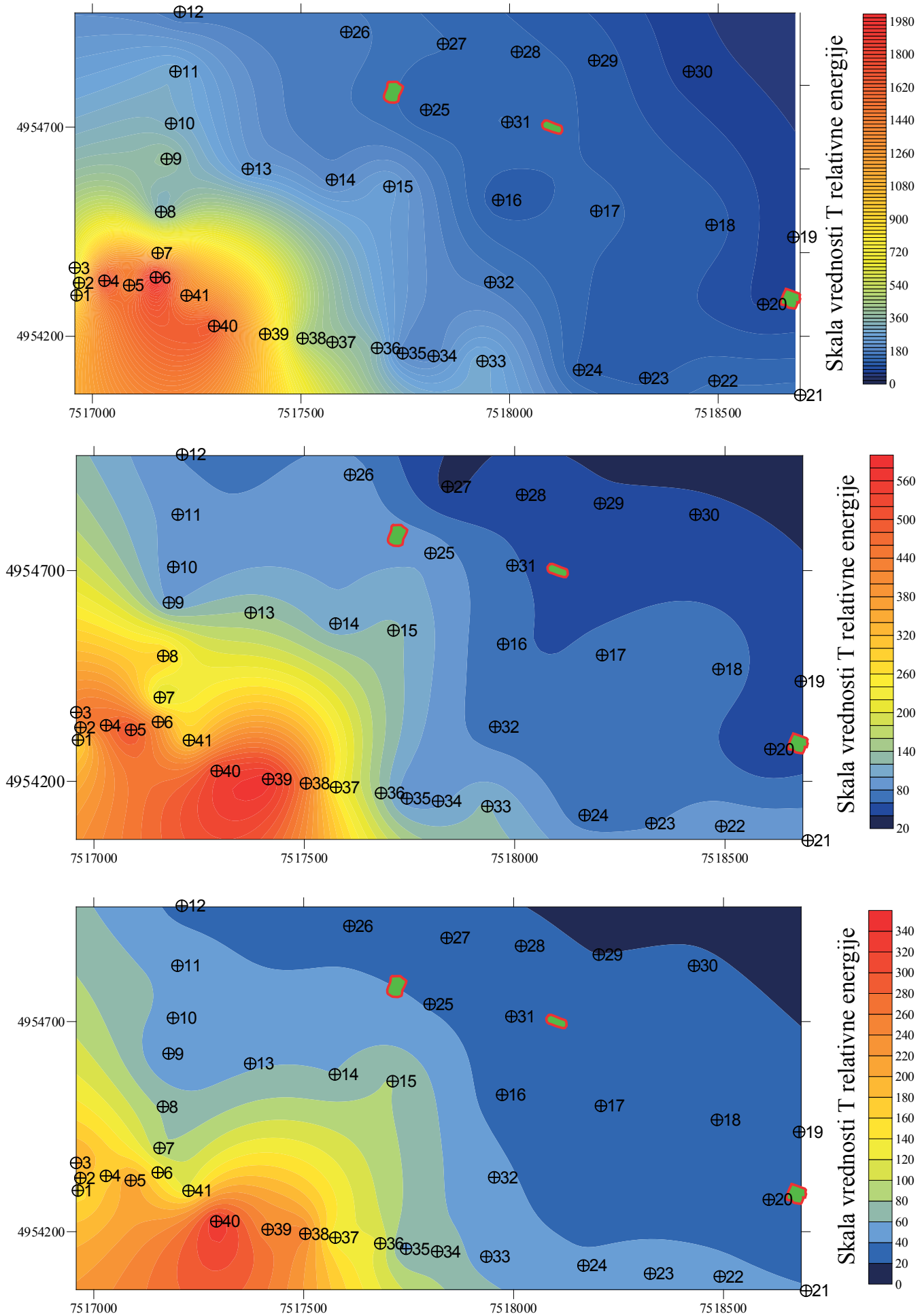

Slika 17. Raspored relativnih energija T komponente: a- od 6 do 9 , b-od 10 do 14 i c- od 15 do $18 \mathrm{~Hz}$ 


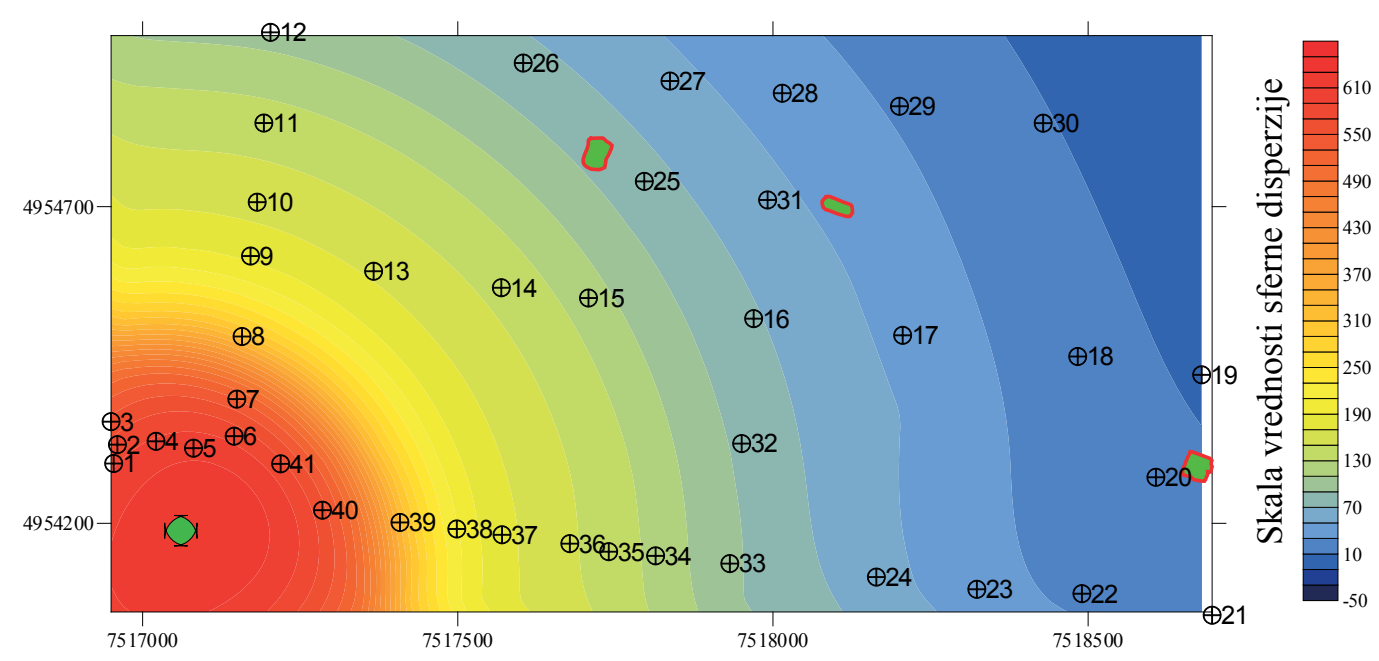

Slika 18. Karta sferne disperzije osmatranih mikrotremora

\section{TEORIJSKE POSTAVKE ZAMORA MATERIJALA}

$\mathrm{Na}$ osnovu obrađenih podataka dobijene su osnovne osobine mikrovibracija, i na osnovu tih vrednosti izračunate njihove brzine po formuli (12). Brzina osmatranih mikrovibracija za tačku koja je uzeta kao karakteristična za termoelektranau (MT6) je $\mathrm{V}_{\text {max }}=1,33 \times 10^{-7} \mathrm{~m} / \mathrm{s}$.

Ako se pogledaju vrednosti dobijene terenskim merenjem i uporede sa vrednostima iz kriterijuma u okviru poglavlja 6.2, primećuje se da su dobijene vrednosti manje od graničnih. Osmatrane mikrovibracije nosioci su mnogo manje energije, manjih su brzina, ali traju neuporedivo duži vremenski period i njihovo prigušenje je sporije. Iz tog razloga, analizirana je pojava oštećenja arheoloških objekata, u vidu zamora materijala, izazvana mikrovibracijama.

Sva tela pod uticajem odgovarajuće sile trpe određene deformacije i po prestanku njenog delovanja vraćaju se u provobitni položaj (elastične deformacije). U slučaju da su te sile velikog intenziteta, dolazi do trajnih deformacija koje se nazivaju plastičnim deformacijama. $\mathrm{Na}$ osnovu brojnih testova, može se konstruisati karakterističan povratni dijagram ovih deformacija (Sl. 23).

Sa slike se vidi da se sa povećanjem napona povećavaju i deformacije, a da se sa prestankom njihovog dejstva telo vraća u prvobitan položaj. Pored elastične deformacije $\left(\delta_{\mathrm{e}}\right)$ telo je zadržalo i nepovratnu (plastičnu) deformaciju $\left(\delta_{t}\right)$. Zbir ovih deformacija predstavlja ukupne defor- macije $\left(\delta_{u}\right)$. Na osnovu ovog principa elastičnih i plastičnih deformacija zasniva se interpretacija dobijenih podataka.

Nisu potrebne samo velike sile da bi dovele do trajnih deformacija, jer mogu i dejstva manjih intenziteta ponavljana u velikom broju ciklusa da izazovu takve promene (zamor materijala).

$\mathrm{Na}$ lokalitetu Viminacium, postoji pojava mikrovibracija izazvanih dejstvom termoelektrane, malih amplituda ali neprekidnog i dugog trajanja. Takvo delovanje vibracija posle određenog vremena izazvaće spuštanje granice između zona elastičnih i plastičnih tj. povratnih i nepovratnih deformacija. Jedna od osobina o kojoj se mora voditi računa i zamor materijala od koga su objekti izgrađeni.

Ovde reč o veoma starim objektima, izgrađenim od opeke i kamena, koji su povezani jednom vrstom maltera, te nije bilo moguće naći tabelarne vrednosti za zamor ovakvog materijala. Reč o materijalu koji je korišćen za izgradnju objekata u period pre oko 1500 godina. Iz tih razloga za defisnisanje zona uticaja mikrovibracija korišćen je kriterijum o zamoru čelika. Čelik kao materijal je dosta elastičnjiji i otporniji na deformacije od gore pomenutog materijala, ali to su bili jedini kriterijumi do kojih se došlo.

Naprezanje koje veliki broj puta može materijal da izdrži, a da se pri tome ne slomi naziva se dinamička čvrstoća $\left(\delta_{\mathrm{d}}\right)$. Lom izazvan višestukim opterećenjem ispod lomne čvrstoće (statičke) naziva se lom od zamora. Ovakav lom nastaje 

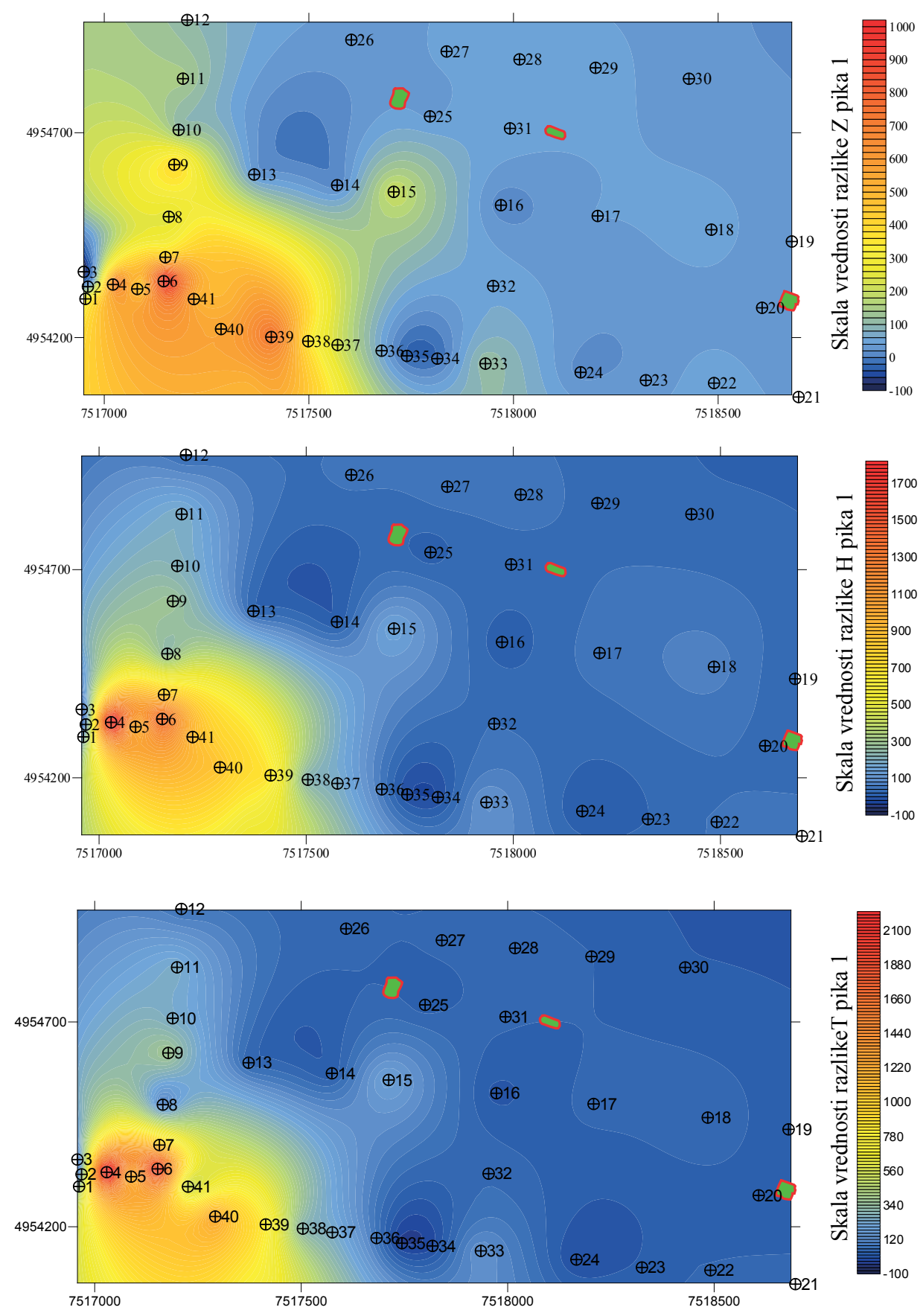

Slika 19. Raspored vrednosti razlike prvog pika: a - Z komponente, b - H komponente i c - T komponente 

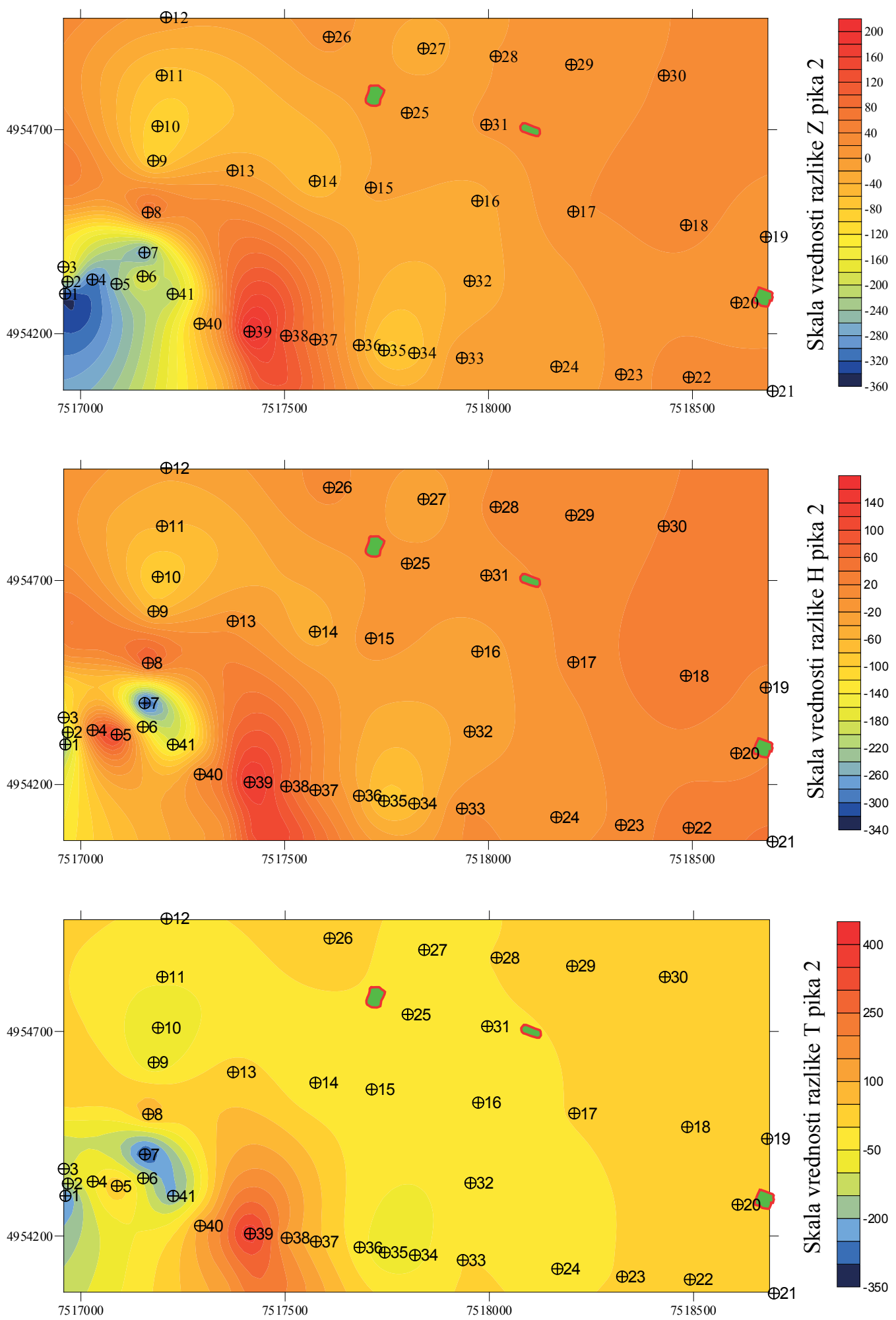

Slika 20. Raspored vrednosti razlike drugog pika: a - Z komponente, b - H komponente i c - T komponente 

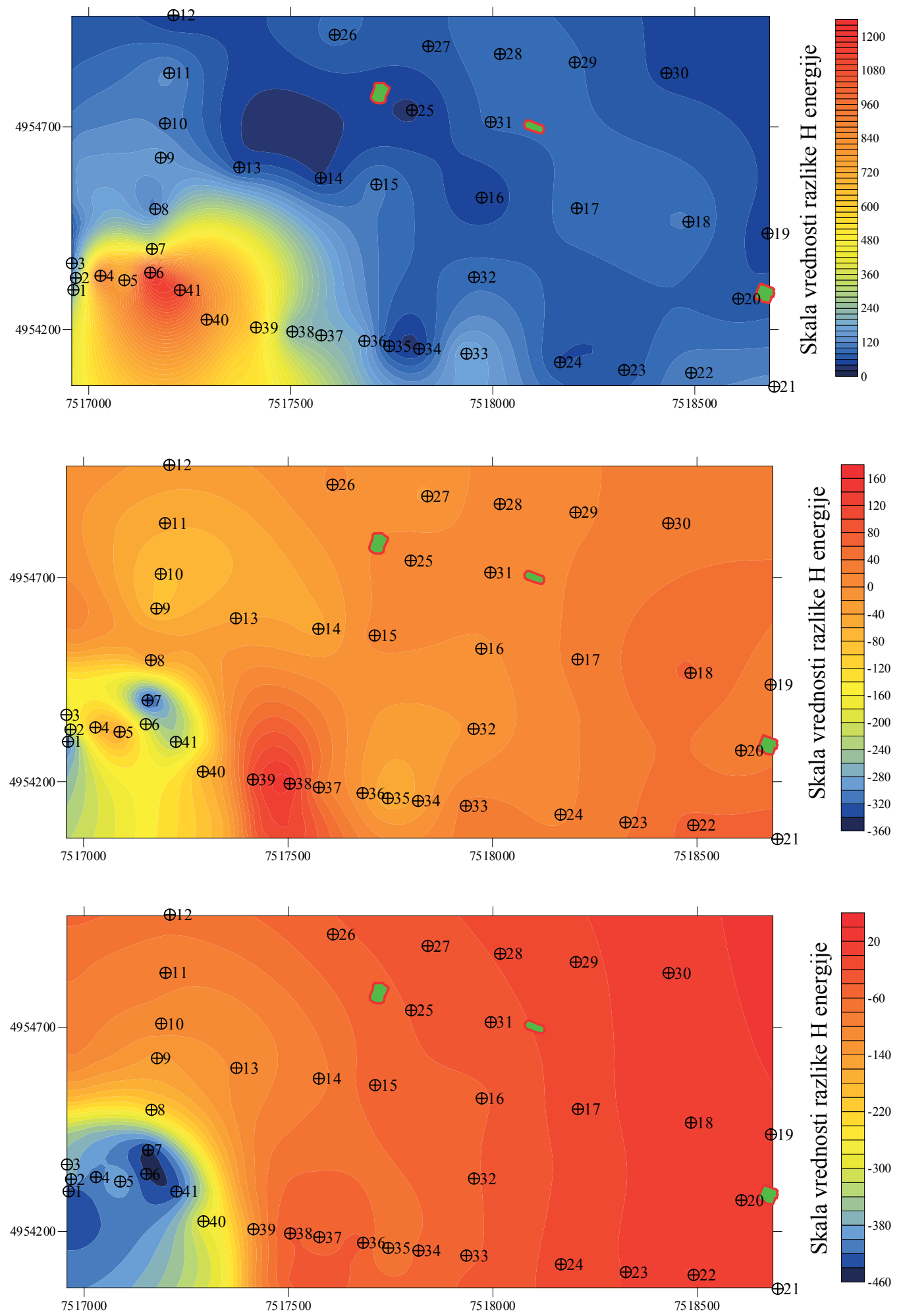

Slika 21. Raspored razlike relativnih energija H komponente:a- od 6 do 9, b-od 10 do 14 i c- od 15 do $18 \mathrm{~Hz}$ 

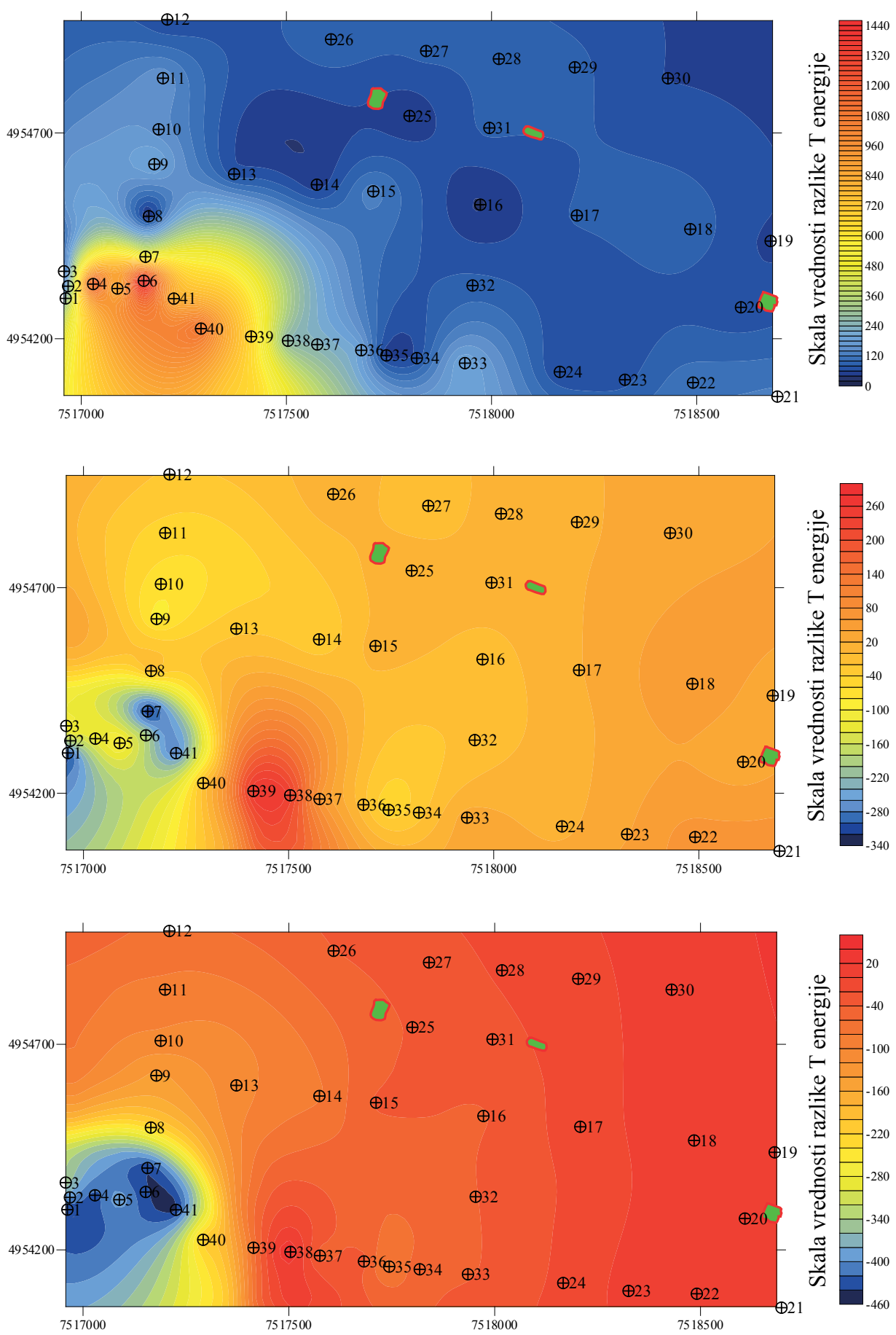

S1. 22 Raspored razlike relativnih energija T komponente: a- od 6 do 9, b-od 10 do 14 i c- od 15 do $18 \mathrm{~Hz}$ 


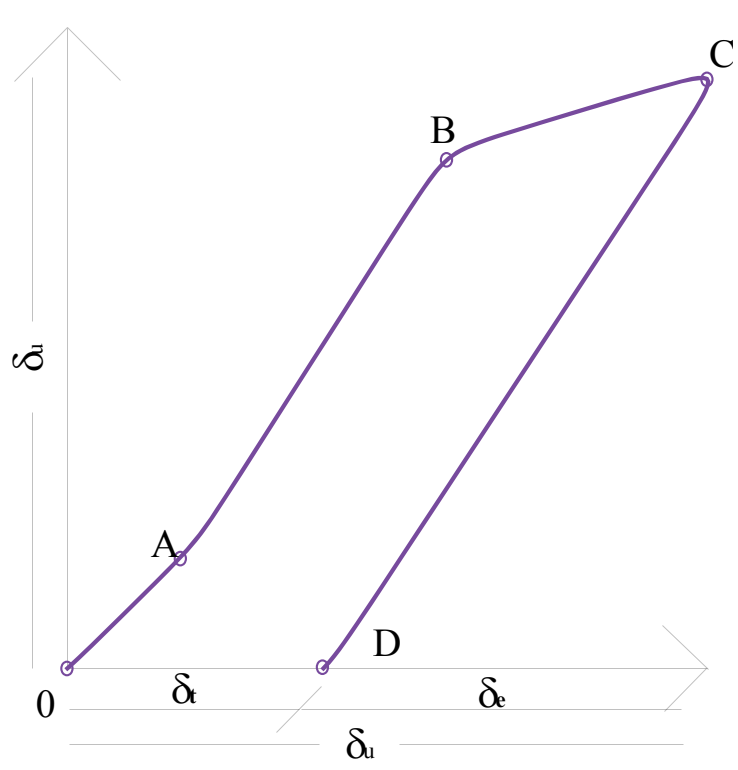

Slika 23. Karakterističan povratni dijagram deformacija

zbog velike lokalne koncentracije naprezanja, a samim tim i nedostatka vremena materijala za prastifikaciju.

Iz velikog broja pokušaja i analiza nije pronađeno precizno fizičko objašnjenje uzroka loma od zamora, niti zakonistost među ovim naprezanjima i brojevima promena opterećenja. Međutim, sa sigurnošću se mogu koristiti grafički prikazi odnosa naprezanja i broja opterećenja do loma. Jedan od takvih prikaza je i Wohlerova kriva (slika 24)

Ova kriva predstavlja prekidnu čvrstoću neizbrušenog elementa iz ČN24 za čisto naizmenično naprezanje kao funkciju broja promena

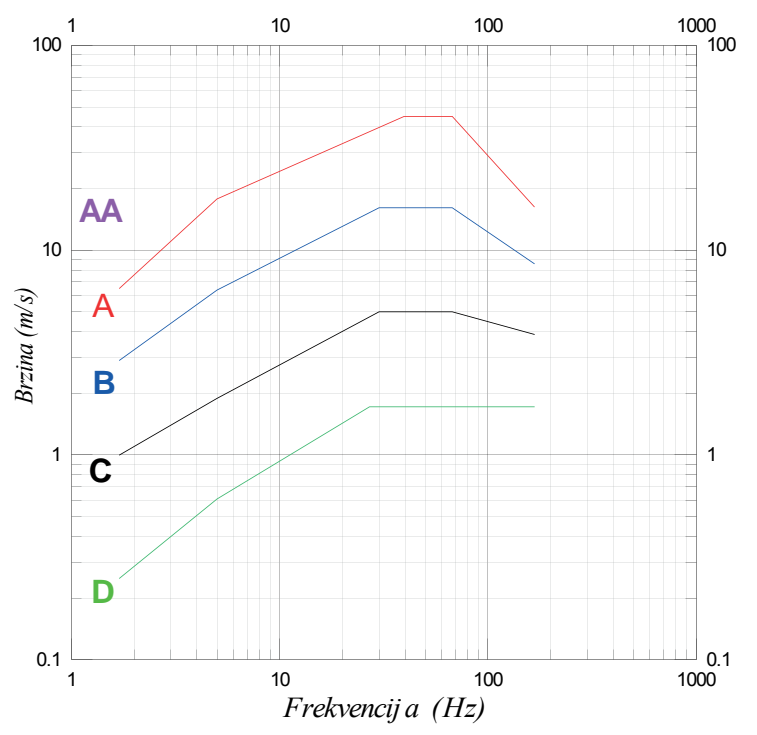

S1. 25 Dijagram graničnih vrednosti brzina za određivanje funkcija koje definišu kategoriju oštećenja opterećenja N, $(i=\log \mathrm{N})$ [7]. Sa ovih dijagrama se uočava da je za čelik broj oscilacija reda $10^{7}$, kada dolazi do loma usled zamora čelika. Pošto je reč o mnogo osetljivijem materijalu za izradu proračuna u ovom radu, kao referentna, usvojena je vrednost $10^{6}$ oscilacija. To je broj oscilacija posle kojih čelik ne menja svoje osobine pre loma, ali se pri ovom broju oscilacija osobine materijala umanje za $65 \%$, odnosno ostvari se $65 \%$ oštećenja.

Za određivanje brzina mikrovibracija koje su osmatrane korišćen je dijagam Blake-a [8] (slika 25). Ovaj dijagram daje granične vrednosti brzina za određene funkcije koje definišu nivo kategorije oštećenja. Dijagram je značajan, jer defi-
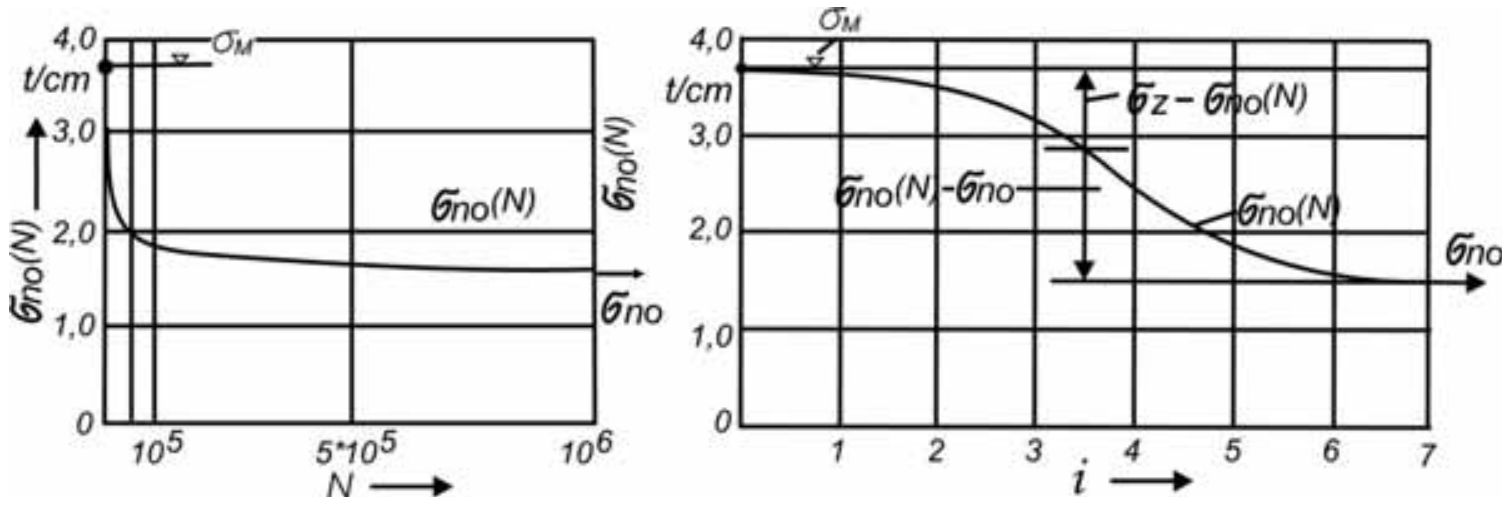

Sl. 24 Wohlerova kriva 
niše brzine mikrovibracija čiji je izvor rad velikih mašina, što je adekvatno uticaju termoelektrane.

Definisano je pet kategorija oštećenja i to:

$$
\begin{aligned}
& \text { D - bez oštećenja } \\
& \text { C - manja oštećenja } \\
& \text { B - oštećenja } \\
& \text { A - veća oštećenja }
\end{aligned}
$$

AA - opasno.

Za potrebe izvedene analize prihvaćena je kategorija oštećenja A i sa pomenutog dijagrama je preuzeta vrednost brzina. Brzina je određivana preko frekvencija karakterističnih tačaka osmatranja za tačku (MT6). Frekvencija mikrotremora čiji je izvor termoelektrana je $8 \mathrm{~Hz}$ i njoj odgovara brzina sa dijagrama od $7,8 \times 10^{-3} \mathrm{~m} / \mathrm{s}$.

\section{INTERPRETACIJA PODATAKA UTICAJA TERMOELEK- TRANE "KOSTOLAC"}

Osmatrane mikrovibracije čiji je stalni izvor termoelektrana imaju brzine mnogo manje nego brzine sa slika 25 . Brzina očitana sa dijagrama iznosi $7,8 \times 10^{-3} \mathrm{~m} / \mathrm{s}$. Na osnovu odnosa brzine sa dijagrama i brzine osmatrane karakteristične tačke (MT6) dobijena je vrednost od 5,9 $\times 10^{4}$ $\left(7,8 \times 10^{-3} \mathrm{~m} / \mathrm{s} / 1,33 \times 10^{-7} \mathrm{~m} / \mathrm{s}\right)$. Ova vrednost pokazuje koliko je puta manja osmatrana brzina od brzina na predstavljenom dijagramu. To pokazuje da je intenzitet oscilacija 10000 puta manji od očekivanog nivoa za čelik. Zbog toga je vršeno povećanje broja oscilacija sa $10^{6}$ na $10^{10}$. Ovaj broj oscilacija koji je potreban da se dođe do gra- nične vrednosti oštećenja, je podeljen sa vrednosti frekvencije osmatranih mikrovibracija $\left(5,9 \times 10^{10} /\right.$ $8 \mathrm{~Hz}$ ).

Ovakvim proračunom dobijen je period od 234 godine, koji predstavlja period za koji će osmatrane mikrovibracije izazvati oštećenje objekta za $65 \%$. Proračun je zasnovan i na tome da u sadašnjem momentu karakterističnu tačku MT6 odlikuje vrednost od 100\%tog oštećenja, a sve druge tačke su, u smislu stepena oštećenja, normirane prema njoj. $\mathrm{Na}$ osnovu ovog podatka vršen je procentualni proračun i za ostale tačke osmatranja (slika 26).

Kao polazna osnova MT6 je bila i pri proračunu nivoa oštećenja za period od 10, 20, 50, 100 i 234 godine Dobijene vrednosti su korišćene za izradu karata procentualnog oštećenja u naznačenim periodima (slika 27 od a do e). $\mathrm{Na}$ ovim kartama je prikazana distribucija oštećenja u osmatranoj oblasti za dati period vremena.

Na prikazanim kartama se vidi da je u svim vremenskim periodima najače oštećenje u jugozapadnom delu koji je i najbliži izvoru mikrovibracija. Od ovog centra vrednosti oštećenja zonarno opadaju sa udaljavanjem od elektrane. Takođe u zapadnom delu svih karata se vidi povećanje oštećenja čiji je izvor najverovatnije bager u površinskom kopu, čiji se uticaj osetio u osmatranoj zoni. Za period od 10 godina se vidi da su arheološki lokaliteti u zoni od 1,2\% oštećenja, za period od 20 godina oštećenje je $2,5 \%$, dok za period od 50 godina oštećenje dostiže vrednost od $6 \%$. Sa karte iscrtane za period vremena od 100 godina

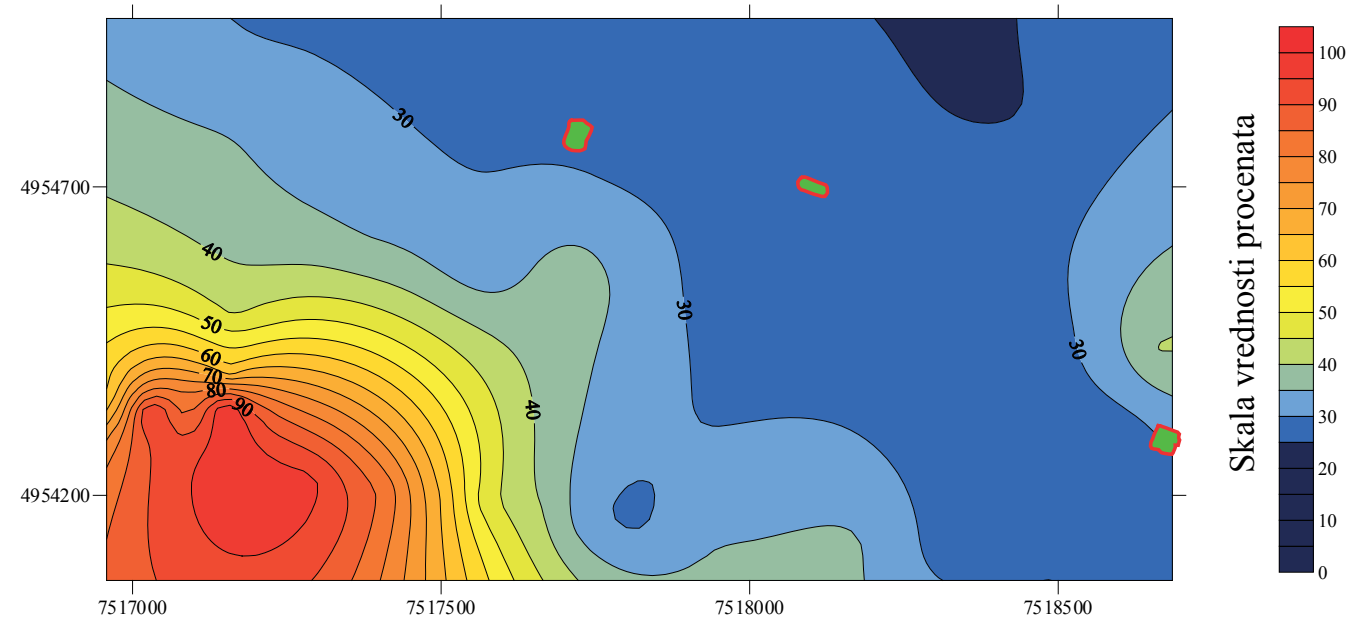

Slika 26. Distribucija procentualnih vrednosti na osnovu tačke MT6 koja je bez oštećenja 

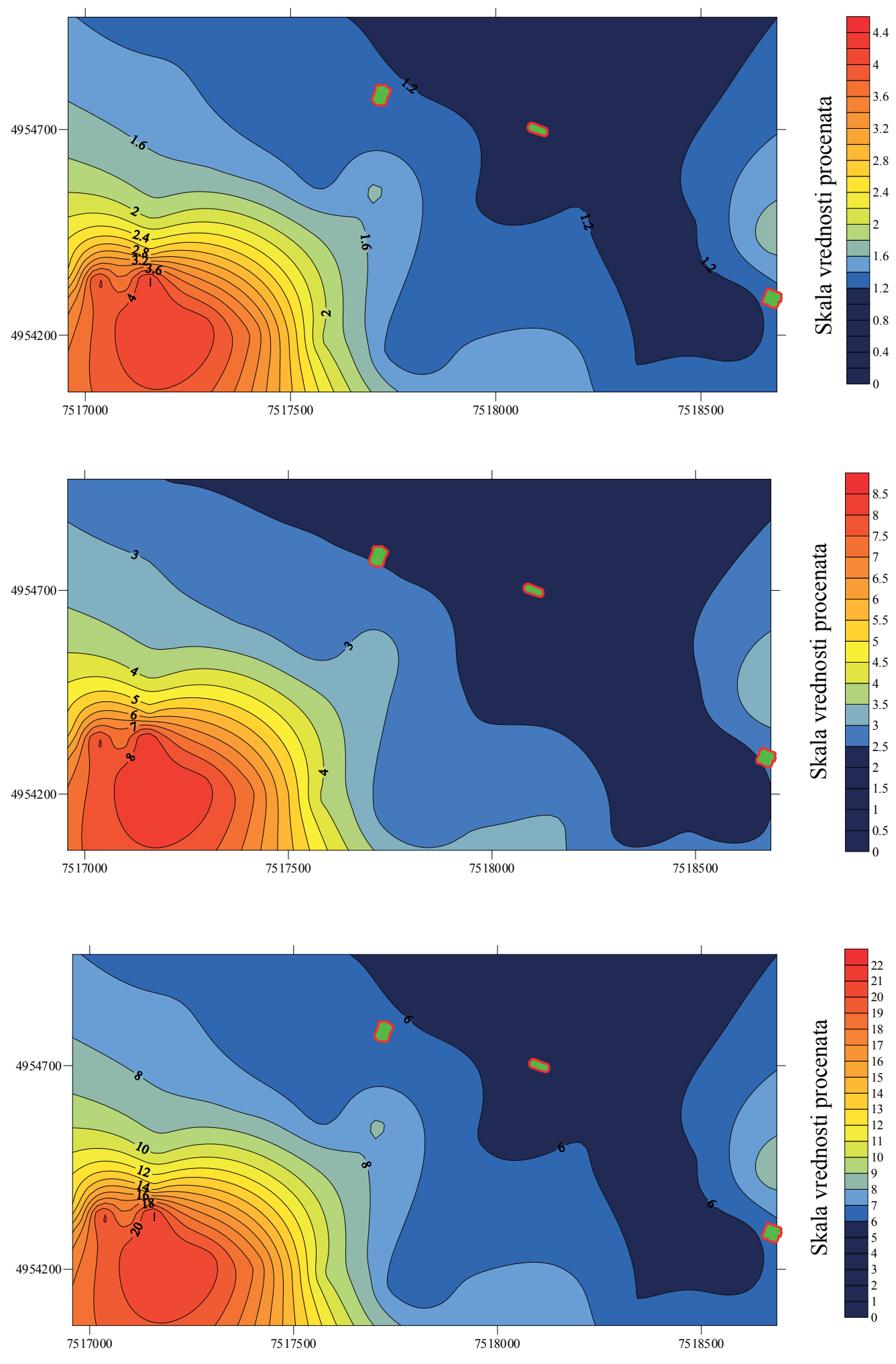

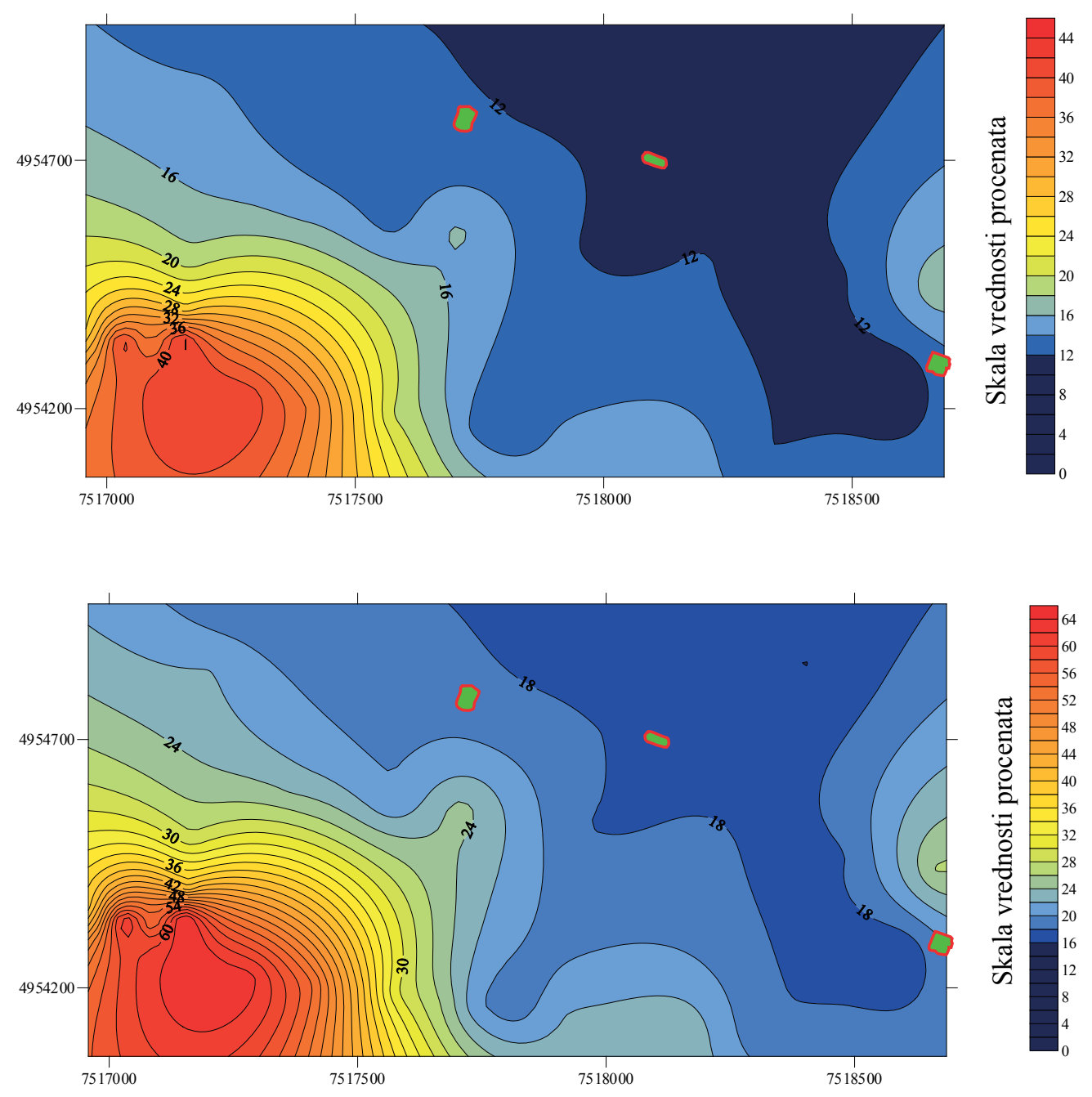

Slika 26. Karte procentualnog oštećenja za: a- 10 god, b- 20 god., c-50 god., d-100 god., e-234 godine

lokalitet je u oblasti oštećenja od $12 \%$. Najveće oštećenje je za proračunatih 234 godine i za tačku MT6 iznosi 65\%, a arheološki lokaliteti su izloženi oštećenju od $18 \%$. Od otkrivenih lokaliteta Terme su najviše ugrožene, jer su i najbliže i izvoru mikrovibracija, dok su Severna kapija i Mauzolej u većini sličajeva nešto manje izložene oštećenju pošto su udaljenije, mada Mouzolej ulazi u zonu povećanih vrednosti na zapadu.

\section{ZAKLJUČAK}

Prilikom izrade ovog rada težilo se određivanju kriterijuma za uticaj mikrovibracija na arheološki lokalitet Viminacium. Na istražnom području postoji stalni izvor - termoelektrana Kostolac. Postojeći kriterijumi za ocenu štete izazvane na objektima se odnose na mikrovibracije čiji su izvori eksplozije. Osmatrane mikrovibracije koje su obrađene ovim radom, odlikuju se malim 
amplitudama, ali dugim vremenskim periodom delovanja na arheološki lokalitet. Zbog toga nije bilo moguće koristiti postojeće kriterijume.

Da bi se došlo do relevantnog kriterijuma, primenjena je teorija o zamoru materijala, a korišćeni su podaci za zamor čelika, iako je on po svojim elastičnim svojstvima mnogo bolji od gore pomenutog materijala. Na osnovu vremena potrebnog da kod čelika dođe do loma, vršeni su proračuni za zamor materijala na arheološkom lokalitetu Viminacium.

$\mathrm{Na}$ osnovu izvršenih proračuna i primenjenog postupka prezentovanom u ovom radu, dobijene su vrednosti za koji vremenski period ove stalne mikrovibracije malih inteziteta izazivaju pojavu trajnih deformacija na objektima arheološkog lokaliteta.

Mikrovibracije čiji je izvor termoelektrana smanjuju ovu granicu za $65 \%$ u periodu od 234 godine. Pored toga, definisane su i karte stepena oštećenja objekata u zoni arheološkog lokaliteta Viminacium, za periode od 10 godina, 20 godina, 50 godina i 100 godina. Ovim radom je potvrđeno da da traženi kriterijumi mogu biti definisani i da je moguće izvršiti kvantitativnu analizu degradacionog uticaja mikrovibracija malih amplituda, ali dugog vremenskog trajanja.

\section{LITERATURA}

[1] Blake M P, 1964: "New Vibration Standards for Maintenance", Hydrocarbon Processing and Petroleum Refiner, Vol 43, \#1, pp 111-114

[2] Domezet Ž, Krsilović-Opra L, 2006.: Podloga za predavanja iz Metalnih konstrukcija i Konstruiranja, Split

[3] http://www.viminacium.org.rs: 2006.

[4] Kuzeljević D, 2006.: "Analiza uticaja antropogenih mikrovibracija na arheološki lokalitet Viminacium”, Diplomski rad, Rudarsko-geološki fakultet, Beograd.

[5] Rakić A, 2005.: Seizmika miniranja, Društvo inženjera i tehničara NIS-Naftagas, Novi Sad
[6] Rakić M, 1980: Tumač za OGK, List "Bela Crkva", Savezni geološki zavod, Beograd

[7] Stojković M, 1983: Istraživanja stacionarnih karakteristika mikrotremora i ekvivalentnih geoloških modela tla, Doktorska disertacija, Skoplje.

[8] Topolac Ž, 1991: Fizika, DIP “Građevinska knjiga", Beograd

[9] Trajković S, Slimak Š, Lutovac S, 2005: Tehnika miniranja i potresa, Rudarsko-geološki fakultet, Beograd

\section{QUANTIFICATION OF DETERIORATING IMPACT OF THE THERMOELECTRIC PLANT DRMNO ON ARCHAEOLOGICAL SITE VIMINACIUM}

In this paper is described the triaxial short time microtremor monitoring, and modelling of acquired data. Monitoring of microtremor is applied in purpose of quantification the degradation on Viminacium archaeological site, caused by micro vibration generated from thermoelectric power plant Drmno. Spectral analyze and calculation of degradation degree in sense of fatigue of materials out of numerous cycles of dynamic load is based to ČN24 steel. 


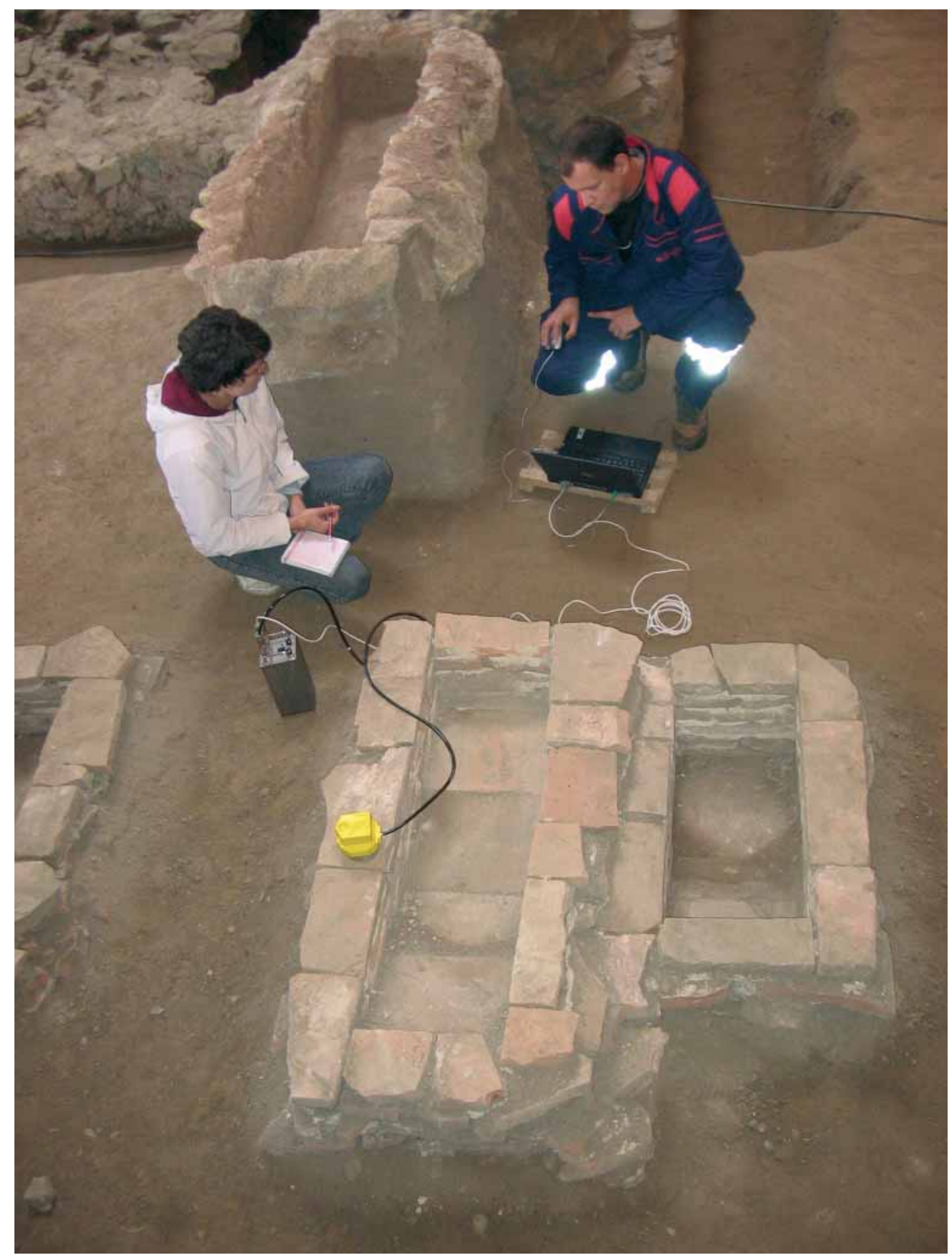

Slika 27. Uzorkovanje mikrotremora u zonama grobnih mesta na Viminaciumu 